NOTE

\title{
HAS DUE PROCESS STRUCK OUT? THE JUDICIAL RUBBERSTAMPING OF RETROACTIVE ECONOMIC LAWS
}

\author{
ANDREW C. WEILER
}

\section{INTRODUCTION}

Fundamental to a civilized and just society is a recognition that citizens should be able to understand the obligations and sanctions that the legal system imposes on them. Retroactive application of the law has historically been seen as inimical to this norm, for it denies individuals the ability both to conform their conduct to what society expects and to forecast the benefits or punishments associated with what they do. Various provisions of the U.S. Constitution reflect the importance of fair notice, including the proscriptions against ex post facto laws, ${ }^{1}$ the imperative of equal protection of the law, ${ }^{2}$ the restraint against impairment of the obligation of contracts, ${ }^{3}$ and the guarantees of due process. ${ }^{4}$ Cases and scholarly comments have criticized retroactive criminal and civil laws as oppressive, unjust, and an illegitimate exercise of legislative power. ${ }^{5}$ Yet despite this apparent hostility to laws that

1. U.S. ConST. art. I, \& 9, cl. 3 ; \& 10, cl. 1.

2. Id. amend. XIV, §1.

3. Id. art. I, \& 10, cl. 1 .

4. Id. amends. V; XIV, \& 1 .

5. See, e.g., Railroad Retirement Bd. v. Alton R.R., 295 U.S. 330, 354 (1935) (holding retroactive imposition of pension liability arbitrary and irrational), overnuled by Usery v. Turner Elkhorn Mining Co., 428 U.S. 1 (1976); Cameron v. United States, 231 U.S. 710,720 (1914) ("It would be subversive of principles of right and justice to give such effect to [the retroactive repeal of] a statute upon the protection of which the petitioner had the right to rely ... ."); Leedom v. International Bhd. of Elec. Workers Local 108, 278 F.2d 237, 240 (D.C. Cir. 1960) ("Antipathy to retroactive lawmaking by legislatures and courts has deep historical roots .... The fundamental unfaimess of retrospective legislation is recognized in American constitutional theory.") (footnote omitted); Dash v. Van Kleeck, 7 Johns. 477, 505-06 (N.Y. 1811) ("An ex post facto law, in the strict teehnical sense of the term, is usually understood to apply to criminal cases, and this is its 
interfere with settled expectations, the U.S. Supreme Court has been surprisingly receptive to the retroactive application of economic legislation, particularly tax legislation: It has articulated a standard of due process review that is as deferential to a legislature's decision to apply an economic law retroactively as it is to a legislature's decision to enact the law at all. According to the Court, as long as the retroactive application of a statute in the field of economic policy is "supported by a legitimate legislative purpose furthered by rational means, judgments about the wisdom of such legislation remain within the exclusive province of the legislative and executive branches." Alongside this mild scrutiny of retroactive economic legislation generally (the "general deference" doctrine), the Court has enunciated for tax legislation specifically an alternative due process standard that, in practice, elevates such legislation to an even higher level of presumptive validity. Under this tax standard (the "tax deference" doctrine), courts are required to "consider the nature of the tax and the circumstances in which it is laid before ... [finding] its retroactive application ... so harsh and oppressive as to transgress the constitutional limitation."7

Two recent decisions of the U.S. Court of Appeals for the Ninth Circuit illustrate the significant confusion generated by these

meaning, when used in the constitution of the United States; yet laws impairing previously acquired civil rights are equally within the reason of that prohibition and equally to be condemned.") (footnote omitted); THE FEDERALIST No. 44 (James Madison); 2 RECORDS OF THE FEDERAL CONVENTION OF 1787, at 376, 378-79 (Max Farrand ed., 1911); Charles B. Hochman, The Supreme Court and the Constitutionality of Retroactive Legislation, 73 HARV. L. REV. 692, 693 (1960) ("[T]here is the strong common-law tradition that although a court's pronouncements may apply to past conduct, a legislature's function is to declare law for the future."); Elmer E. Smead, The Rule Against Retroactive Legislation: A Basic Principle of Jurisprudence, 20 MINN. L. REv. 775, 789 (1936) ("[W]e find the courts holding that retroactive laws which impaired vested rights were contrary to justice, violations of the social compact or of the very principles upon which our government was based, or were not properly an exercise of the legislative power at all.").

6. Pension Benefit Guar. Corp. v. R.A. Gray \& Co., 467 U.S. 717, 729 (1984); see also General Motors Corp. v. Romein, 112 S. Ct. 1105, 1112 (1992); United States v. Sperry Corp., 493 U.S. 52, 64 (1989); Usery v. Turner Elkhorn Mining Co., 428 U.S. 1, 16-17 (1976).

7. United States v. Hemme, 476 U.S. 558, 568-69 (1986) (quoting Welch v. Henry, 305 U.S. 134, 147 (1938)); accord United States v. Darusmont, 449 U.S. 292, 299 (1981) (per curiam). Although it has explained that the "harsh and oppressive" language "does not differ from the prohibition against arbitrary and irrational legislation," Pension Benefit, 467 U.S. at 733, the Supreme Court has not refuted the extreme presumption of constitutionality for tax legislation that has evolved from the application of this "harsh and oppressive" standard. See infra text accompanying notes 64-105. 
facially distinct juridical standards and highlight the toothless scrutiny of retroactive economic laws that stems from their use. ${ }^{8}$ The Ninth Circuit's use of divergent due process analyses to reach opposing conclusions as to the constitutionality of two retroactive congressional acts has brought into sharp focus the questionable perpetuation of the tax/non-tax distinction, the elusive justifications for and appropriate applications of the tax/non-tax standards, and the demonstrable evisceration of meaningful judicial inquiry into economic retroactivity. Ultimately, the Ninth Circuit's struggle reveals the incoherence and inadequacy of the current methods of due process review and underscores the need for a heightened degree of protection for the public from retroactive economic Jaws.

An examination of the dual system of review created by the Supreme Court's formulation of the tax deference and general deference doctrines discloses three overarching infirmities. First, the extreme deference to retroactive tax laws, effected through the tax deference doctrine, mistakenly assumes that all retroactive tax legislation is less offensive to due process than other retroactive economic legislation. This artificial separation of economic laws through a tax/non-tax inquiry proves overinclusive with respect to tax legislation, and thus improperly handicaps taxpayers' due process challenges.

Second, the ambiguity of the general deference doctrine's "arbitrary and irrational" language and the tax deference doctrine's "harsh and oppressive" language creates problems of practical application. Notably, the two doctrimes have evaded systematic judicial implementation, as courts have failed to agree on the necessary elements of a due process review under either standard.

Third, the lenient level of judicial review permitted under both doctrines neglects the inherent injustice of retroactive laws and inappropriately discounts the deeply rooted jurisprudential and constitutional aversion to retroactivity. The Court's allowance of such a minimal inquiry into retroactive economic legislation has encouraged the modern trend toward the judicial rubberstamping of such laws. ${ }^{9}$ Significantly, since the origination of the tax defer-

8. See Carlton v. United States, 972 F.2d 1051, 1055-56 (9th Cir. 1992), petition for reh'g filed, Sept. 29, 1992; Licari v. Commissioner, 946 F.2d 690 (9th Cir. 1991).

9. Cf. William W. Van Alstyne, The Second Death of Federalism, 83 MicH. L. REv. 
ence doctrine in $1938,{ }^{10}$ the Supreme Court not only has never sustained a due process challenge to the retroactive application of a tax law, ${ }^{11}$ but, more remarkably, has not sustained a due process challenge to any retroactive economic law. ${ }^{12}$ With judicial deference becoming de facto judicial abdication, a central question emerges: Is the Constitution as accommodating as the Supreme Court to retroactivity in the economic arena? Applying the lowest possible level of judicial scrutiny to laws that upset past expectations ultimately enables Congress to exercise greater authority than should constitutionally be permissible and threatens to leave the courts with questionable doctrinal tools to use in increasingly extreme instances of retrospective regulation.

1709 (1985) (criticizing judicial abdication in the commerce-federalism area).

10. See Welch v. Henry, 305 U.S. 134 (1938). The tax deference doctrine requires a court "to consider the nature of the tax and the circumstances in which it is laid" in order to determine whether "its retroactive application is so harsh and oppressive" as to offend due process. Id. at 147.

11. See United States v. Hemme, 476 U.S. 558 (1986) (upholding an estate and gift tax against a due process challenge); United States v. Darusmont, 449 U.S. 292 (1981) (per curiam) (upholding a retroactive income tax provision against a due process challenge); Fernandez v. Wiener, 326 U.S. 340 (1945) (upholding a federal estate tax against a due process challenge); see also Fein v. United States, 730 F.2d 1211 (8th Cir.) (upholding retroactive repeal of an estate tax exclusion for life insurance policies), cert. denied, 469 U.S. 858 (1984); Estate of Ceppi v. Commissioner, 698 F.2d 17 (1st Cir.) (upholding retroactive repeal of estate tax exclusion), cert. denied, 462 U.S. 1120 (1983); Buttke v. Commissioner, 625 F.2d 202 (8th Cir. 1980) (upholding retroactive application of income tax amendment), cert. denied, 450 U.S. 982 (1981); Purvis v. United States, 501 F.2d 311 (9th Cir. 1974) (upholding retroactive application of interest equalization tax on foreign stock acquisitions), cert. denied, 420 U.S. 947 (1975).

12. See, e.g., General Motors Corp. v. Romein, 112 S. Ct. 1105, 1112 (1992) (upholding retroactive legislation affecting Michigan's compensation benefits law because of the legislation's curative nature); United States v. Sperry Corp., 493 U.S. 52 (1989) (upholding retroactive effect of federal legislation with respect to the costs of an international claims tribunal); Pension Benefit Guar. Corp. v. R.A. Gray \& Co., 467 U.S. 717 (1984) (upholding retroactive effect of federal legislation imposing liability for withdrawal from pension plans); Usery v. Turner Elkhorn Mining Co., 428 U.S. 1 (1976) (upholding retroactive effect of federal law imposing liability on coal mine employers for employee disabilities caused by black limg disease); Galvan v. Press, 347 U.S. 522 (1954) (upholding retroactive application of federal legislation concerning immigration and deportation of aliens); Chase Sec. Corp. v. Donaldson, 325 U.S. 304 (1945) (upholding repeal of statute of limitations which deprived defendant of his sole defense); Parainino Lumber Co. v. Marshall, 309 U.S. 370 (1940) (upholding legislation that reopened a workers' compensation proceeding after the time for judicial appeal had expired); Battaglia v. General Motors Corp., 169 F.2d 254 (2d Cir.) (upholding the 1947 Portal-to-Portal Act's retroactive bar of employees' clains to the recovery of statutory overtime formerly permittcd under the Fair Labor Standards Act of 1938), cert. denied, 335 U.S. 887 (1948). 
The retroactive application of new or amended law raises several distinct issues. This Note does not examine the retroactive application of decisional law; ${ }^{13}$ nor does it consider the limits on state legislation imposed by the Contract Clause or what rules of statutory construction or interpretation ought to govern when civil statutes do not specify whether they apply retroactively. ${ }^{14}$ Rather, this Note focuses on the degree to which the courts perceive the Due Process Clauses of the Constitution as barriers to retroactivity in economic laws. ${ }^{15}$

Part I compares the strong historical tradition of criticism of retroactivity with the Supreme Court's current extraordinary tolerance to retroactive economic laws instituted through the tax deference and general deference doctrines. Part II uses the Ninth Circuit's decisions in Licari v. Commissioner ${ }^{16}$ and Carlton $v$. United States ${ }^{17}$ to demonstrate the lack of clarity and insufficiency of the two doctrines, as well as their putative independent existences. Part III explores the roots and rationality of the doctrines and documents the diverse and often expendable reasons for the permissiveness of retroactivity. This analysis reveals that the tax deference doctrine has incrementally enveloped all retroactive tax laws within its deferential fold, thereby shielding every tax presented to the federal courts in an armor of constitutionality that has proved impenetrable. ${ }^{18}$ This bright-line grouping of all taxes into a special category of review has unjustifiably elided the significant variances among tax laws-an outcome the tax deference

13. See, e.g., Barry R. Ostrager, Retroactivity and Prospectivity of Supreme Court Constitutional Interpretations, 19 N.Y. L.F. 289 (1973); Orvill C. Snyder, Retrospective Operation of Overruling Decisions, 35 ILL. L. REV. 121 (1940).

14. See, e.g., Gregory J. Demars, Retrospectivity and Retroactivity of Civil Legislation Reconsidered, 10 OHIO N. U. L. REV. 253 (1983). Nor does this Note consider the scrutiny accorded retroactive civil legislation arising outside of the economic context.

15. The Supreme Court has not treated the scrutiny of retroactivity in the economic arena as varying depending upon whether it is the Due Process Clause of the Fifth or Fourteenth Amendment that is allegedly violated. Rather, the two Clauses have been similarly applied. See Welch v. Henry, 305 U.S. 134, 149 (1938) (analyzing Fourteenth Amendment due process challenge to retroactivity by analogizing it to Fifth Amendment due process cases).

16. 946 F.2d 690 (9th Cir. 1991).

17. 972 F.2d 1051 (9th Cir. 1992), petition for reh'g filed, Sept. 29, 1992.

18. Indeed, if Carlton were to be upheld, it would be the first such invalidation of a retroactive tax under the Due Process Clauses of the federal constitution since the Supreme Court set forth over half a century ago the tax deference doctrine in Welch $\mathbf{v}$. Henry, 305 U.S. 134 (1938). 
doctrine's logical and precedential bases fail to support. Given its admission of the confluence of the tax deference and general deference doctrines, ${ }^{19}$ the Supreme Court should formulate a single standard of review applicable to both tax and non-tax retroactive economic laws that by its terms more readily upholds certain retroactive taxes (such as income taxes) without mandating the sweeping approval of all other retroactive tax legislation.

Part III also concludes that the Supreme Court has, by design or neglect, threatened to cast the due process review of retroactivity by the judicial wayside. Neither the tax deference doctrine nor the general deference doctrine adequately elevates the courts' scrutiny of the retroactive aspects of a law above the meaningless inquiry into its prospective aspects allowed by the judiciary's abdication in the substantive economic due process field..$^{20}$ In light of the Court's continued recognition of the "problems of unfairness" inherent in retroactive laws, ${ }^{21}$ this dissonant result appears intolerable.

Thus, Part IV reconsiders the appropriate level of scrutiny to be accorded all retroactive economic legislation. A comparison of possible alternative standards of review ${ }^{22}$ instructs that the courts should resist the rubberstamping of such legislation by applying a modified and strengthened rationality test that balances the government's interest in applying the law retroactively with the individual's interest in fair notice and settled expectations. Such a test would resemble the four-part rationality analysis for retroactive legislation employed in the highly analogous Contract Clause context, $^{23}$ a standard of review the Supreme Court has only cursorily treated in the area of retroactivity and too abruptly disre-

19. Pension Benefit Guar. Corp. v. R.A. Gray \& Co., 467 U.S. 717, 733 (1984); accord Rhinebarger v. Or, 839 F.2d 387, 389 (7th Cir.) ("Following the Supreme Court's lead, we also treat these as the same standard."), cert. denied, 488 U.S. 824 (1988); see supra text accompanying note 7 .

20. See infra text accompanying notes $40-41$.

21. General Motors Corp. v. Romein, 112 S. Ct. 1105, 1112 (1992).

22. Part IV looks at three possible alternatives to the current mere rationality review: (1) the two-part inquiry offered by the Carlton majority, (2) an intermediate level of review demanding a showing that the retroactivity period is necessary to accomplish an important government objective, and (3) a rationality analysis similar to that employcd in Contract Clause cases dealing with federal legislation that has retroactive effects.

23. See Shelter Framing Corp. v. Pension Benefit Guar. Corp., 705 F.2d 1502 (9th Cir. 1983), rev'd sub nom. Pension Benefit Guar. Corp. v. R.A. Gray \& Co., 467 U.S. 717 (1984); Nachman Corp. v. Pension Benefit Guar. Corp., 592 F.2d 947, 961-63 (7th Cir. 1979), affd on statutory grounds, 446 U.S. 359 (1980). 
garded. ${ }^{24}$ This test would examine: (1) the existence or absence of notice, (2) the reliance interests of the affected parties, (3) the equities of imposing the retroactive burdens, and (4) the statutory provisions that limit and moderate the impact of the burdens. Adoption of such a test would provide lower courts with a more definitive and judicious analysis of retroactive economic laws than that currently offered under the tax deference and general deference doctrines, as well as promote greater predictability and uniformity in the law.

Under this reinvigorated due process analysis, rationales deemed legitimate when considering the prospectivity of economic legislation would undergo greater scrutiny when used to justify the retroactivity of such laws. This review would allow the invalidation of the laws at issue in Licari and Carlton without necessarily undermining the validity of prior Supreme Court decisions. More importantly, such a standard of review would arrest the postLochner ${ }^{25}$ devitalizing of due process protection in this area, retard the lower federal courts' troubling slide down the slippery slope of permissible retroactivity, and more fully safeguard the public's right, under the Constitution, to know the law.

\section{Covering the Bases: The Evolution of the General DEFERENCE AND TAX DEFERENCE DOCTRINES}

The U.S. Supreme Court's evolution of the general deference and tax deference doctrines has worked a significant departure from the long-standing condemnation of retroactivity evidenced in judicial theory and practice. The courts' historically cautious approach to retroactivity contrasts sharply with the current level of deference to retroactivity in the economic arena demanded by the two doctrines. Examination of the development of the two doctrines reveals how the Court has chosen to value the economic

24. Pension Benefit Guar. Corp. v. R.A. Gray \& Co., 467 U.S. 717, 727 \& n.6, 732-33 (1984). With the advantage of hindsight, it has becoine apparent that the Court's avoidance of this type of rationality standard has resulted in the meaningless scrutiny of retroactivity that at least one circuit court feared would arise. See Nachman, 592 F.2d at 960 n.26 ("Although explicit consideration of these [four rationality analysis] factors might suggest a risk of judicial usurpation of properly legislative judgments, failure to consider them might ultimately result in no meaningful scrutiny of the legislative process-a result prohibited by the Due Process Clause.").

25. Lochner v. New York, 198 U.S. 45 (1905), overruled by Day-Brite Lighting, Inc. v. Missouri, 342 U.S. 421 (1952). 
aspect of retroactive economic laws at the expense of their retroactive feature. This misplaced emphasis on the traditional deference accorded legislatures when they enact prospective economic laws has resulted in a level of due process review that excessively defers to legislative determinations of the constitutionality of retroactive economic laws. Such deference undervalues the importance of settled expectations and adequate notice and undermines the citizenry's right to reasonable reliance on the law.

\section{A. A National Pastime: The Condemnation of Retroactivity ,}

With origins in Greco-Roman law, ${ }^{26}$ the bias against retroactivity $^{27}$ in American jurisprudence was an early import from the English common law. ${ }^{28}$ Hostility to retroactive laws rests not only upon a sense of simple unfairness, but more specifically upon the belief that they destroy predictability and undercut reliance-two central concerns of the law. ${ }^{29}$ For a populace to accept rule by law willingly, the law must appear reasonable. To be reasonable, the law must afford those governed the ability to maintain reasonable control over their destinies, through, inter alia, the knowledge of the consequences of given conduct. ${ }^{30}$ Retroactive laws violate

26. See CODE J. 1.14.7; see also Ray H. Greenblatt, Judicial Limitations on Retroactive Civil Legislation, 51 Nw. U. L. REV. 540, 540 (1956); Smead, supra note 5, at 775.

27. Retroactive laws apply to prior acts, events, or occurrences, and seek to impose new consequences on such past conduct. Some commentators have distinguished between "retroactive" laws-laws that operate legally for a period before the statutes' effective dates of enactment-and "retrospective" laws-laws that operate forward but attach new future legal consequences to past acts. See, e.g., Demars, supra note 14, at 255-56. However, because most civil statutes that affect past acts operate both retrospectively and retroactively, and because courts and scholars alike often treat the two terms synonymously, id. at 257 , differentiating between these two definitions is unnecessary for the purposes of this Note.

28. See Smead, supra note 5 , at $780,797$.

29. Leedom v. International Bhd. of Elec. Workers Local 108, 278 F.2d 237, 240 (D.C. Cir. 1960).

30. See, e.g., ANDREW AlTMAN, CRITCAl LEgal StUdies: A LiBERAL CRITIQUE 107 (1990) (Rules "provide[] citizens with a clear advance warning of the conditions under which public power will be deployed and how it will be deployed. This is a virtue because citizens can then choose their activities secure in the belief that they will not be bringing down the coercive hand of state power upon themselves."); id. at 112 ("The principal fornal virtue of the rule form ... is that it provides people with a clear and unequivocal specification of what the state requires of them .... In the jargon of legal theory, rules provide 'fair notice.' "); Russell L. Weaver, Retroactive Regulatory Interpretations: An Analysis of Judicial Responses, 61 NOTRE DAME L. REV. 167, 168 n.3 (1986) (quoting 2A C. DALlas SANDS, SUTHERLAND STATUTORY CONSTRUCTION \& 41.02, at 247 (4th ed. 1972)) ("It is a fundamental principle of jurisprudence that retroactive appli- 
this principle because they deny notice, thereby lessening the legitimacy of law as a means of governance. ${ }^{31}$

The most forceful expression of this rule against retroactivity arises in the Ex Post Facto Clause of the Constitution. However, the Supreme Court in Calder v. Bull ${ }^{32}$ restricted that clause to criminal legislation. This limitation, coupled with the fact that the Contract Clause is incapable of reaching either state legislative activity affecting noncontractual relations or any federal legislation, ${ }^{33}$ led courts initially to appeal to the Cokean tradition of natural law in denouncing retroactive civil legislation. ${ }^{34}$ Yet, due

cation of new laws involves a high risk of being unfair. There is general consensus among all people that notice or warning of the rules that are to be applied to determine their affairs should be given in advance of the actions whose effects are to be judged by them.").

31. Although one can defend the maxim that ignorance of the law is no defense to violations of the law, it is hard to defend the proposition that activity in accordance with the law should lead to unexpected and expensive consequences when the law is changed retroactively.

32. 3 U.S. ( 3 Dall.) 386 (1798). Although it is now well settled that the Ex Post Facto Clause applies only to penal legislation, the validity of this assertion has not gone unquestioned. For a discussion of the controversy surrounding the scope of the Ex Post Facto Clause and an examination of the evidence supporting the position that the Clause ought to apply to both civil and criminal retroactive laws, see Smead, supra note 5, at 791 \& n.51. See also Dash v. Van Kleeck, 7 Johns. 477, 505-06 (N.Y. 1811) (challenging the theoretical consistency in prohibiting retroactive criminal legislation while permitting retroactive civil legislation).

33. Pension Benefit Guar. Corp. v. R.A. Gray \& Co., 467 U.S. 717, 732 n.9 (1984).

34. For example, in Fletcher v. Peck, 10 U.S. (6 Cranch) 87 (1810), the Court made a strong appeal to natural law to invalidate the Georgia legislature's revocation of land grants made by an earher Georgia congress: "It is, then, the unanimous opinion of the court, that .... the state of Georgia was restrained, either by general principles which are common to our free institutions, or by the particular provisions of the constitution of the Umited States .... Id. at 139. In a separate opinion, Justice Johnson expressed his willimgness to strike down the legislature's act solely on higher law grounds: "I do not hesitate to declare that a state does not possess the power of revoking its own grants. But I do it on a general principle, on the reason and nature of things: a principle which will impose laws even on the deity." Id. at 143 (Johnson, J., concurring in part and dissenting in part). Likewise, in Terrett v. Taylor, 13 U.S. (9 Cranch) 43 (1815), the Court stated:

But that the legislature can repeal statutes creating private corporations, or confirming to them property already acquired under the faith of previous laws ... . we are not prepared to admit; and we think ourselves standing upon the principles of natural justice, upon the fundamental laws of every free government, upon the spirit and letter of the constitution of the United States, and upon the decisions of most respectable judicial tribunals, in resisting such a doctrine.

Id. at 52; see also Van Kleeck, 7 Johns. at 502-03 ("The very essence of a new law is a rule for future cases ... a principle which has become venerable for the antiquity and the universality of its sanction, and is acknowledged as an element of jurisprudence."). 
to the questionable authority of higher law as a legitimate basis for restraining legislative action, ${ }^{35}$ the rule against retroactivity eventually evolved from its natural law moorings into a constitutional principle assimilated into the Due Process Clauses. ${ }^{36}$

Due process requires that citizens have the means to know the law-it is the denial of this ability that underlies the injustice of retroactive laws. ${ }^{37}$ Such laws enable a legislature to impose new restrictions or penalties on past actions, thus preventing citizens from avoiding the laws' application because the proscribed conduct is already complete. As Justice Story remarked, "Retrospective laws are, indeed, generally unjust; and, as has been forcibly said, neither accord with sound legislation nor with the fundamental principles of the social compact." ${ }^{\prime 38}$ This awareness of retroactivity's potential injustice reveals itself in the judiciary's practice of presuming that legislation operates only prospectively absent clear indication of retroactive effect. ${ }^{39}$ Thus, it is in the context of this jurisprudential and constitutional aversion to retroactivity that the current presumption of validity accorded retroactive economic laws becomes so alarming.

35. See, e.g., LON L. FULLER, THE LAW IN QUEST OF ITSELF 119-20 (1940) (discussing in the context of early legal positivism the opprobrium against judicial reliance on natural law).

36. Greenblatt, supra note 26 , at 543; Smead, supra note 5, at 790-91.

37. See Benjamin N. CARDozo, THE Growth of THE LAW 3 (1924) ("Law as a guide to conduct is reduced to the level of mere futility if it is unknown and unknowable.").

38. 2 JOSEPH STORY, COMMENTARIES ON THE CONSTTTUTION OF THE UNITED STATES § 1398 (5th ed. 1891).

39. See Luddington v. Indiana Bell Tel. Co., 966 F.2d 225, 228 (7th Cir. 1992) ("A legislature has awesome power uncabined by a professional tradition of modesty and this power is held a little in check by the presumption that its handiwork is to be applied only to future conduct."), petition for cert. filed, 61 U.S.L.W. 3446 (U.S. Dec. 3, 1992) (No. 92-977); see also Billings v. United States, 232 U.S. 261, 282 (1914) (noting that "the rule is that statutes should be so construed as to prevent them from operating retroactively"); Reynolds v. McArthur, 27 U.S. (2 Pet.) 417, 434 (1829) ("It is a principle which has always been held sacred in the United States, that laws by which human action is to be regulated look forwards, not backwards; and are never to be construed retrospectively, unless the language of the act shall render such construction indispensable."). 


\section{B. A Policy of General Admission: Retroactive Economic Legislation}

The lenient level of judicial scrutiny accorded retroactivity in the economic arena has its foundations in the Supreme Court's post-Lochner era abandonment of substantive economic due process review. ${ }^{40}$ Under this token scrutiny, legislative acts adjusting the benefits and burdens of economic life have possessed a presumption of constitutionality that has proven irrebuttable. ${ }^{41}$ Modern expression as to the relation between such judicial abdication and retroactive economic legislation is found in the Court's decision in Usery v. Turner Elkhorn Mining $\mathrm{Co}^{42}$ In Turner Elkhorn, the Court considered a due process challenge to the retrospective effects of the Federal Coal Mine Health and Safety Act of 1969, as amended by the Black Lung Benefits Act of 1972. Through the Black Lung amendment, the 1969 Act required a coal mine operator to provide compensation for a former employee's death or disability due to pneumoconiosis (black lung disease) arising out of employment in its mine, even if employment ended not only before the Act became law, but even before the legislation was first considered by Congress. ${ }^{43}$ After emphasizing the well-established rule to presume the constitutionality of prospective economic legislation, ${ }^{44}$ the Court stated that "[i]t does not follow . . . that what Congress can legislate prospectively it can legislate retrospectively. The retrospective aspects of legislation, as well as the prospective aspects, must meet the test of due process, and the justifications for the latter may not suffice for the former." ${ }^{45}$ In applying this assertion, the Court noted that it would "hesitate to approve the retroactive imposition of liability on any theory of deterrence...

40. See, e.g., Ferguson v. Skrupa, 372 U.S. 726 (1963); Williamson v. Lee Optical Co., 348 U.S. 483 (1955).

41. See, e.g., William Lockhart ET AL, CONSTTtutional LAW 401 (6th ed. 1985) (noting that the Court has not struck down an economic regulation for violating substantive due "process since 1937); Robert G. McCloskey, Economic Due Process and the Supreme Court: An Exhumation and Reburial, 1962 SUP. CT. REv. 34, 40-45 (offering reasons for the judiciary's abdication in the field of economic due process).

42. 428 U.S. 1 (1976).

43. Id. at 5 .

44. Id. at 15.

45. Id. at 16-17. 
or blameworthiness," ${ }^{36}$ for even if the employers knew of the dangers of black lung disease, they relied upon the current state of the law, which imposed no liability. ${ }^{47}$ Nevertheless, the Court concluded that the "imposition of liability [on the Operators] for the effects of disabilities bred in the past is justified as a rational measure to spread the costs of the employees' disabilities to those who have profited from the fruits of their labor . . ." 48 Thus, although the Court upheld the law because of the strong public policy interest involved, its rationale explicitly questioned the soundness of a deterrence or blameworthiness theory for validating such retroactive legislation.

In Pension Benefit Guaranty Corp. v. R.A. Gray \& Co. ${ }^{49}$ the Court reaffirmed the Turner Elkhorn analysis and seemed to eliminate any doubt as to whether the deference accorded retroactive laws equalled that accorded prospective legislation. The issue in Pension Benefit was whether the application of the withdrawal liability provisions of the Multiemployer Pension Plan Amendments Act of 1980 (MPPAA) ${ }^{50}$ to employers withdrawing from pension plans during a five-month period before the law's enactment violated the Due Process Clause of the Fifth Amendment. ${ }^{51}$ Pointing to the language in Turner Elkhorn that upheld the retrospective application of liability because it was a "rational" measure, ${ }^{52}$ the Court explained that the "strong deference" accorded economic legislation "is no less applicable when that legislation is applied retroactively." 53 As for the admonition in Turner Elkhorn that the justifications for the future effects of a law may not suffice to defend its retroactive aspects, the Court concluded that "that burden is met simply by showing that the retroactive application of the legislation is itself justified by a rational legislative purpose. ${ }^{" 54}$ Finding that the MPPAA's short period of retroactivi-

46. Id. at 17-18 (citations omitted).

47. Id. at 17. Importantly, the Court did not suggest that if the Operators knew of the dangers of black lung disease, retrospective imposition of liability would be justified under a theory of blameworthiness.

48. Id. at 18.

49. 467 U.S. 717 (1984).

50. 29 U.S.C. §§ 1381, 1391 (1982).

51. 467 U.S. at $719-20$.

52. Id. at 730 .

53. Id. at 729 .

54. Id. at 730 . 
ty was "necessary to accomplish [Congress's] purposes"5s of preventing the possible collapse of multiemployer plans and the substantial undercutting of the new legislation by the pre-enactment withdrawal of employers from the plans, ${ }^{56}$ the Court sustained the law as satisfying due process.

In United States v. Sperry Corp. ${ }^{57}$ the Court characterized the general deference doctrine set forth in Turner Elkhorn and refined in Pension Benefit as settled law. Upholding the retroactive imposition of a fee on parties who used the Iran-United States Claims Tribunal to validate their settlement awards, the Court observed, "It is surely proper for Congress to legislate retrospectively to ensure that costs of a program are borne by the entire class of persons that Congress rationally believes should bear them." Fi Finally, in its most recent case on the topic, General Motors Corp. v. Romein, ${ }^{59}$ the Court gave cursory treatment to a due process challenge to a Michigan law that retroactively overruled a Michigan Supreme Court decision regarding the state's workers' compensation law. The Court remarked that "[r]etroactive legislation presents problems of unfairness that are more serious than those posed by prospective legislation, because it can deprive citizens of legitimate expectations and upset settled transactions." ${ }^{\prime 60}$ Not surprisingly, the Court found no such problems in Romein. It effectively treated the retroactive legislation as curative in nature and held that the approximately six-year period of retroactivity was a rational means of achieving the legitimate objective of correcting a court's unexpected interpretation of a law. ${ }^{61}$

Thus, relying on the high degree of deference accorded the prospective application of economic laws, the Supreme Court has instituted an equally high degree of deference to a legislature's decision to apply such laws retrospectively. Although the courts may find different reasons for the prospective and retrospective application of a law, they will nevertheless be equally deferential to the legislature, requiring only some rational basis. Moreover,

\footnotetext{
55. Id. at 731 .

56. Id. at $730-31$.

57. 493 U.S. 52 (1989).

58. Id. at 65 (citing Pension Benefit, 467 U.S. at 730; Turner Elkhom, 428 U.S. at

59. 112 S. Ct. 1105 (1992).

60. Id. at 1112.

61. Id.
} 18). 
because the rational basis need not be one expressed by the legislature, but can be one imputed by the advocates or the courts themselves, ${ }^{62}$ the test for economic retroactive legislation appears to have been reduced to a quest for any rational grounds that can be manufactured to uphold a law. ${ }^{63}$ Amazingly, tax legislation is allegedly entitled to an even lesser review.

\section{A League of Its Own: Retroactive Tax Legislation}

The groundwork for the tax deference doctrine arose from the undoubted power of Congress and the states to tax and the courts' reluctance to interfere with such taxation. Even at the height of the Lochner era, ${ }^{64}$ when judicial use of the Due Process Clause of the Fifth Amendment to scrutinize prospective legislation regulating private business was at its peak and tax measures were struck down on other grounds, ${ }^{65}$ the Supreme Court deprived the Due Process Clause of virtually any effect on the federal taxing power. ${ }^{66}$ As the Supreme Court stated in Brushaber v. Union Pacific Railroad, "[T] 67 Constitution does not conflict with itself by conferring upon the one hand a taxing power and taking the same power away on the other by the limitations of the due process clause." ${ }^{.68}$

The consequence of this attitude was the consistent rejection during the nineteenth and early twentieth centuries of due process challenges to retroactive income tax laws. ${ }^{69}$ However, the Court in a series of pre-New Deal cases resisted its historical leniency by

62. Cf. Williamson v. Lee Optical Co., 348 U.S. 483, 487 (1955) (Court engaging in speculation as to the legislature's reasons for enacting law regulating fitting or duplicating of eyeglass lenses).

63. This development is particularly disturbing in light of the fact that it is difficult to find legislation that does not, in one manner or another, affect the benefits and burdens of economic life. Ultimately, it can be argued that any law that does not inpinge on a fundamental right appears to fall under the economic rubric.

64. Lochner v. New York, 198 U.S. 45 (1905), overruled by Day-Brite Lighting, Inc. v. Missouri, 342 U.S. 421 (1952).

65. See, e.g., Bailey v. Drexel Furniture Co., 259 U.S. 20 (1922) (Child Labor Tax Case) (striking down a tax on products created by child labor as a punitive, not a taxing, measure).

66. Boris I. Bittker, Constitutional Limits on the Taxing Power of the Federal Govemment, 41 TAX LAW. 1, 11 (1987).

67. 240 U.S. 1 (1916).

68. Id. at 24 .

69. These cases and an examination of their precedential value are discussed infra notes $188-205$ and accompanying text. 
invalidating a line of retroactive federal gift and estate tax provisions as arbitrary and capricious. In Nichols $v$. Coolidge ${ }^{70}$ the Court held that an estate tax offended the Fifth Amendment's Due Process Clause when it included in the gross estate the value of property transferred by a decedent before enactment of the tax. ${ }^{71}$ In Blodgett $v$. Holden, ${ }^{72}$ the Court struck down the retroactive application of the nation's first federal gift tax as violative of due process because it reached actions completed before the tax was even introduced in Congress. The plurality concluded that "[i]t seems wholly unreasonable that one who, in entire good faith and without the slightest premonition of such consequence, made absolute disposition of his property by gifts should thereafter be required to pay a charge for so doing." ${ }^{, 73}$ This rationale was readjusted in Untermyer $v$. Anderson, ${ }^{74}$ where, faced with the identical situation as in Blodgett except for the fact that the taxpayer in Untermyer had acted after the tax was pending before Congress, the Court considered the constructive notice distinction immaterial:

The mere fact that a gift was made while the bill containing the questioned provisions was in the last stage of progress through Congress we think is not enough ... to relieve the legislation of the arbitrary character there ascribed to it. To accept the contrary view would produce insuperable difficulties touching interpretation and practical application of the statute, and render impossible proper understanding of the burden intended to be imposed. The taxpayer may justly demand to know when and how he becomes liable for taxes-he cannot foresee and ought not to be required to guess the outcome of pending measures. The future of every bill while before Congress is necessarily

70. 274 U.S. 531 (1927).

71. Id. at $542-43$.

72. 275 U.S. 142 (1927), modified, 276 U.S. 594 (1928). The Court in Blodgett actually split 4-4 (only eight Justices participated in the decision) as to why the statute did not apply retroactively. Four Justices relied on the due process argument, while the other four alleged that the statute ought to be construed only to apply prospectively, thereby avoiding the retroactivity issue altogether. Notably, Justice Holmes, in a concurring opinion, implied that a retroactive tax affecting such a vesting of a gift would be intolerable because it would "impose an unexpected liability that if known might have induced those concerned to avoid it and to use their money in other ways." Id. at 149 (Holmes, J., concurring).

73. Id. at 147.

74. 276 U.S. 440 (1928). 
uncertain. The will of the lawmakers is not definitely expressed until final action thereon has been taken. ${ }^{75}$

Concurring in Untermyer, Justice Brandeis worried that the majority's rule would render Congress powerless to prevent the evasion of imminent law by citizens who anticipate legislation's passage with wariness; consequently, he argued that a retroactivity period should be permissible if it is needed to prevent such evasion. ${ }^{76}$ Finally, early in the New Deal Era, in Helvering $v$. Helmholz ${ }^{77}$ and White $v$. Poor, ${ }^{78}$ the Court reaffirmed its objection to retroactive estate tax provisions on due process grounds, arguing that an irrevocable trust had been created before enactment and that upsetting such settled transfers was unconstitutional.

Despite the invalidation of these tax laws under a rationality standard, the Court in the seminal case of Welch v. Henry ${ }^{79}$ implicitly lowered the appropriate level of scrutiny accorded such retroactive legislation by distinguishing the tax laws from other economic legislation generally. ${ }^{80}$ At issue in Welch was the constitutionality of a Wisconsin income tax law that retroactively taxed dividends received from a specified category of corporations previously exempt from such taxation. Enacted in 1935 as an emergency measure to raise revenue to meet the unemployment relief demands caused by the Great Depression, the Wisconsin tax applied back over two years to the taxable years 1933 and $1934 .{ }^{81}$ Writing for the 6-3 majority upholding the statute, Justice Stone declared the rationale underlying the permissiveness of tax retroactivity:

Taxation is neither a penalty imposed on the taxpayer nor a liability which he assumes by contract. It is but a way of apportioning the cost of government among those who in some measure are privileged to enjoy its benefits and must bear its burdens. Since no citizen enjoys immunity from that burden, its

75. Id. at $445-46$.

76. Id. at 450-51 (Brandeis, J., concurring) ("Is Congress powerless to prevent such evasion by the vigilant and ingenious? . . . I see no reason why it may not spread a tax over a period in advance of its enactment sufficiently long to insure that the tax will not be evaded by anticipating the passage of the act.").

77. 296 U.S. $93,97-98$ (1935).

78. 296 U.S. 98, 102 (1935).

79. 305 U.S. 134 (1938).

80. Id. at $146-47$.

81. Id. at $141-42$. 
retroactive imposition does not necessarily infringe due pro-

Noting the Court's prior allowance of retroactive income taxes, the Court provided a two-part guideline for determining whether a tax law's retroactive application is "so harsh and oppressive as to transgress the constitutional limitation." ${ }^{83}$ A court is to consider both "the nature of the tax and the circumstances in which it is laid." Distinguishing Welch from the previous cases invalidating the retrospective imposition of gift taxes, ${ }^{85}$ the Court first found that the nature of the tax in question could not reasonably have affected a taxpayer's actions: "We can not assume that stockholders would refuse to receive corporate dividends even if they knew that their receipt would later be subjected to a new tax or to the increase of an old one." ${ }^{186}$ The Court also emphasized the particular need for allowing income tax retroactivity:

[E]xperience has shown the importance of reasonable opportunity for the legislative body, in the revision of tax laws, to distribute increased costs of government among its taxpayers in the light of present need for revenue and with knowledge of the sources and amounts of the various classes of taxable income during the taxable period preceding revision. Without that opportunity accommodation of the legislative purpose to the need may be seriously obstructed if not defeated. We cannot say that the due process which the Constitution exacts denies that opportunity to legislatures; that it withholds from them, more than in the case of a prospective tax, authority to distribute the increased tax burden ....87

This special claim for tax legislation was buttressed by the Court's assertion that no taxpayer could "assert surprise. or complain of arbitrary action in the retroactive apportionment of tax burdens to income at the first opportunity after knowledge of the nature and amount of the income is available." ${ }^{\text {s8 }}$ As for the over-two-year

82. Id. at $146-47$.

83. Id. at 147.

84. Id.

85. See Coolidge v. Long, 282 U.S. 582 (1931); Untermyer v. Anderson, 276 U.S. 440

(1928); Nichols v. Coolidge, 274 U.S. 531 (1927); supra text accompanying notes 70-76.

86. Welch, 305 U.S. at 148.

87. Id. at 149.

88. Id. at $149-50$. 
period of retroactivity, the Court noted that "[f]or more than seventy-five years it ha[d] been the familiar legislative practice of Congress in the enactment of revenue laws to tax retroactively income or profits received during the year of the session in which the taxing statute is enacted, and in some instances during the year of the preceding session." Although the statute in Welch reached back one year further than this traditional allowance, the Court held that this unprecedented length did not violate due process, because the Wisconsin legislature met only biennially and thus 1935 was the "first opportunity" the legislature had to revise its laws for $1933 .{ }^{90}$

The dissenting Justices argued that a proper reading of the Untermyer line of cases warranted the conclusion that the taxpayer could not have foreseen the nature and amount of the retroactive income tax in Welch when he paid his 1933 income tax. ${ }^{91}$ Most significantly, the dissenters disagreed with the majority's extension of the "recent transactions" rationale to two years before enactment, arguing that this was an inappropriate expansion of prior cases. $^{92}$ In addition, the dissenters posited that if a tax had been retrospectively imposed on places of religious worship that had long received tax-exempt status, the Court's holding would certainly have been otherwise ${ }^{93}$ - the suggestion being that the "harsh and oppressive" standard was too open-ended because it left too much discretion to the court's conscience.

In 1981, the Supreme Court in United States v. Darusmont ${ }^{94}$ fully reexamined the tax deference standard enunciated by the Welch majority. In Darusmont, the taxpayer alleged that the retroactive application of a 1976 minimum tax provisions amendment to the Internal Revenue Code to a transaction fully consummated before the amendment became effective violated due process. In this case, the period of retroactivity was about four months. After the District Court for the Eastern District of California invalidated the retroactive application of the law, ${ }^{95}$ the Supreme Court took direct appeal and reversed. Asserting that it is "customary congres-
89. Id. at 148 .
90. Id. at $150-51$.
91. Id. at 158 (Roberts, J., dissenting).
92. Id. at $157-58$.
93. Id. at 159.
94. 449 U.S. 292 (1981) (per curiam).
95. Darusmont v. United States, 1980 WL 1648 (E.D. Cal. 1980). 
sional practice" to apply tax codes retroactively for "short and limited periods" of time $e^{96}$ and that the legitimacy of the practice "cannot be doubted," the Court in a per curiam opinion reaffirmed the principle enunciated in Brushaber v. Union Pacific Railroad $^{98}$ and upheld in Welch, that an income tax law will not be declared unconstitutional merely because it affects prior, but recent, transactions. ${ }^{99}$ The Court noted that taxpayers must accept the possibility that tax rates can change retroactively by act of Congress because "[n]obody has a vested right in the rate of taxation." 100 Once this special deference was affirmed, it was a simple step for the Court to uphold the tax law against the taxpayer's due process challenge.

Finally, the Supreme Court in United States v. Hemme $e^{101}$ further refined the tax deference doctrine, stating that one of the relevant circumstances as to the constitutionality of a retroactive $\operatorname{tax}$ "is whether, without notice, a statute gives a different and more oppressive legal effect to conduct undertaken before enactment of the statute." ${ }^{102}$ At issue in Hemme was the validity under the Fifth Amendment's Due Process Clause of an allegedly retroactive federal statute with respect to the taxation of gifts and estates. ${ }^{103}$ Reversing the district court's determination that the law violated due process, Justice Marshall, writing for a unanimous Court, emphasized that the amount of tax involved, although not dispositive, was a relevant factor. ${ }^{104}$ Finding that the taxpayers had actually paid less estate tax under the allegedly retroactive law than they would have if it had never been enacted, the Court held that such a situation confirmed the conclusion that the taxpayers "have not suffered different and oppressive treatment as a result of the [law]." ${ }^{105}$ In effect, the Court merely determined that

96. 449 U.S. at $296-97$.

97. Id. at 297 (quoting Stockdale v. Insurance Cos., 87 U.S. (20 Wall.) 323, 331 (1874)).

98. 240 U.S. 1,20 (1916).

99. Darusmont, 449 U.S. at 300-01.

100. Id. at 298 (quoting Judge Learned Hand in Cohan v. Commissioner, 39 F.2d 540, 545 (2d Cir. 1930)).

101. 476 U.S. 558 (1986).

102. Id. at 569 .

103. The transaction at issue occurred two years before enactinent of the unified credit law challenged by the taxpayers. Id. at 571 .

104. Id.

105. Id. The issue of whether or not the taxpayer had actually suffered a inonetary 
there was no injury and hence no legitimate basis for asserting a due process argument.

In light of the Court's continued rejection of due process challenges to both tax and non-tax retroactive economic laws, it is not clear just how the tax deference and general deference doctrines differ in operation. Differentiating between the nearly irrebuttable validity of tax legislation and the strongly presumed validity of other economic legislation essentially becomes inconsequential to the ultimate determination of constitutionality. As two recent decisions in the Ninth Circuit demonstrate, this meaningless scrutiny creates confusion, demanding reconsideration of these two approaches.

\section{SwITCH-HITTING: THE NiNTH CIRCUIT's StRUgGLE}

The decisions of the U.S. Court of Appeals for the Ninth Circuit in Licari v. Commissioner ${ }^{106}$ and Carlton v. United States ${ }^{107}$ expose the weaknesses in application and problems of scrutiny under the tax deference and general deference doctrines. In Licari, the Ninth Circuit demonstrated the dramatic effect of the presumption of constitutionality accorded retroactive economic laws in upholding against a due process challenge the longest period of retroactivity for a noncurative ${ }^{108}$ tax law ever considered by the courts (almost four years). ${ }^{109}$ Analyzing the case un-

loss under the retroactive law was hotly disputed by the taxpayer, who argued that the decedent's situation should not be compared "to that of another taxpayer subject to \& 2035 [the old law], but to that of a person who did not die within three years of making the gift ...." Id. at 570-71. The Court rejected this argument, holding that such a person was "not similarly situated with respect to the relevant legal criteria," and that this was thus an improper operative comparison. Id. at 571.

106. 946 F.2d 690 (9th Cir. 1991).

107. 972 F.2d 1051 (9th Cir. 1992), petition for reh'g filed, Sept. 29, 1992.

108. Curative legislation is generally defined as legislation enacted to cure defects in prior law. 2A SANDS, supra note $30, \$ 41.11$, at 289. For a more detailed discussion of curative laws, see Hochman, supra note 5, at 703-06.

109. Retroactive taxes upheld by the federal courts have typically had a retroactivity period of approximately two years or less. See, e.g., United States v. Hemme, 476 U.S. 558 (1986) (less than one month); United States v. Darusmont, 449 U.S. 292 (1981) (per curiam) (approximately ten months); Welch v. Henry, 305 U.S. 134 (1938) (two years permitted because of the revenue crisis of the Great Depression and because the state legislature only met biennially); Estate of Ekins v. Commissioner, 797 F.2d 481 (7th Cir. 1986) (less than two years); Fein v. United States, 730 F.2d 1211 (8th Cir.) (less than two years), cert denied, 469 U.S. 858 (1984); Estate of Ceppi v. Commissioner, 698 F.2d 17 (1st Cir.) (less than two years), cert. denied, 462 U.S. 1120 (1983). Two tax law cases which have upheld a retroactivity period of similar length to Licari both involved cura- 
der both the "extremely weighty deference"110 accorded retroactive tax laws under the tax deference doctrine, and the "strong deference"111 accorded other retroactive economic laws under the general deference doctrine, the court approved the retroactive increase of a tax penalty because it was a rational means for the government to recoup the costs of ferreting out tax underpayments. ${ }^{112}$

In contrast to Licari, in Carlton the Ninth Circuit, over a dissenting opinion, struck down on due process grounds the retroactive application of an amendment designed to eliminate an Employee Stock Ownership Plan (ESOP) estate tax deduction. Underlying the decision was the court's recognition that the taxpayer "engaged in a costly transaction for no other reason than the inducement provided by [the tax incentive] ${ }^{\prime 113}$ and that the government was essentially seeking to punish a taxpayer for conduct that Congress had specifically encouraged in order to increase employee ownership of corporations. Although its finding of unconstitutionality initially appears to be an example of the substantive protection offered taxpayers under the tax deference standard, the majority arguably has exceeded the boundaries of the hazy due process analysis discoverable in prior Supreme Court cases, leaving its ruling susceptible to possible reversal.

The Carlton decision's susceptibility to reversal despite its equitable result accentuates the vitiated nature of the minimum rationality test and the egregious negation of settled expectations which is permitted under this standard. A more detailed analysis of these two cases identifies the several problems that pervade the due process field and provides a springboard for examining the rationales other federal courts have used when scrutinizing retroactivity in the economic arena.

tive legislation aimed not at creating a new rate or penalty but rather at preserving congressional intent. See Canisius College v. United States, 799 F.2d 18 (2d Cir. 1986), cert. denied, 481 U.S. 1014 (1987); Teinple Univ. v. United States, 769 F.2d 126 (3d Cir. 1985), cert. denied, 476 U.S. 1182 (1986); see also supra text accompanying notes 59-61 (discussing General Motors Corp. v. Romein, 112 S. Ct. 1105 (1992)).

110. Licari, 946 F.2d at 694 .

111. Id.

112. Id. at 694-95.

113. Carlton v. United States, 972 F.2d 1051, 1059 (9th Cir. 1992), petition for reh'g filed, Sept. 29, 1992. 
A. The Foul Ball: Licari v. Commissioner

In April 1986, the Internal Revenue Service (IRS) asserted that Anthony and Mildred Licari had substantially understated their income taxes for 1982, 1983, and 1984. When the Licaris had filed the returns in question, and even when the IRS issued its Notice of Deficiency, the penalty for substantial understatement under I.R.C. $\S 6661$ was ten percent of the underpayment. ${ }^{114}$ As noted in the Senate Report on the 1982 enactment of section 6661, this penalty was to deter taxpayers from playing the "audit lottery"-that is, taking questionable, but non-negligent, positions on their returns in the hope that these positions would not be challenged by the IRS in an audit. ${ }^{115}$ However, effective October 21, 1986, Congress, in passing section 8002 of the Omnibus Budget Reconciliation Act of 1986 (OBRA) to amend section 6661 increased this penalty from ten percent to twenty-five percent of the underpayment. ${ }^{116}$ This increased penalty was to apply to all penalties assessed "after the date of the enactment of this Act,"117 thus extending back the period of retroactivity for unassessed understatements over three and a half years to the initial effective date of section $6661 .^{118}$

Granting the Tax Commissioner's motion to assess the increased penalty against the Licaris, the Tax Court dismissed, inter alia, the taxpayers' due process challenge. ${ }^{119}$ Recognizing the ex-

114. Enacted in September 1982, § 6661 applies to returns due to be filed after December 31, 1982. Tax Equity and Fiscal Responsibility Act of 1982, Pub. L. No. 97-248, § 323(c), 96 Stat. 324, 613 (1982); Licari, 946 F.2d at 691 n.2. According to the original version of $\S 6661$, "[i]f there is a substantial understatement of income tax for any taxable year, there shall be added to the tax an amount equal to 10 percent of the amount of any underpayment attributable to such an understatement." I.R.C. $\S$ 6661(a) (1982) (repealed 1989). A "substantial understatement of income tax" occurs if "the amount of the understatement for the taxable year exceeds the greater of 10 percent of the tax required to be shown on the return for the taxable year, or . . \$ \$5,000." Id. $\S 6661(\mathrm{~b})(1)(\mathrm{A})(\mathrm{i})-(\mathrm{ii})$.

115. S. REP. No. 494, 97th Cong, 2d Sess. 272-73 (1982), reprinted in 1982 U.S.C.C.A.N. 781, 1019-20.

116. Pub. L. No. 99-509, § 8002, 100 Stat. 1874, 1951 (1986) [hereinafter OBRA]. Section 6661 was subsequently repealed by $\S 7721$ (c)(2) of the Omnibus Budget Reconciliation Act of 1989, which enacted a unified penalty scheme to tax returns due after December 31, 1989, to be applied prospectively. Pub. L. No. 101-239, § 7721(c)(2), 103 Stat. 2106, 2395 (1989).

117. OBRA, supra note $116, \S 8002(\mathrm{~b})$.

118. See Licari, 946 F.2d at 692-93.

119. Licari v. Commissioner, 58 Tax Ct. Mem. Dec. (CCH) 1119, 1126 (1990), affd, 946 F.2d 690 (9th Cir. 1991). 
tremely weighty deference accorded tax legislation and ignoring the distinction between a tax and a penalty, the Tax Court held that Congress's desire "to raise revenue, to deter non-compliance, and to compensate the Government for the cost of enforcing the tax laws" was a rational means used to pursue a legitimate aim, and hence constitutional. ${ }^{120}$ On appeal, the Ninth Circuit criticized the Tax Court's decision to apply the tax deference doctrine and recommended that the penalty instead be examined under the general deference doctrine. Nonetheless, the Ninth Circuit affirmed the Tax Court's holding, stressing that "the retroactive application of the increased tax penalty on those who would gain by understatement is a rational means by which to guard the public fisc by reimbursing the government for the heavy burden of investigative and prosecutorial costs incident to ferreting out tax underpayment." 121

The Ninth Circuit in Licari faced the initial task of determining what standard of review ought to apply to a tax penalty when its retroactive application is alleged to violate due process. Acknowledging the "extremely weighty deference accorded tax rates," 122 and even noting that "to the best of our knowledge, the Supreme Court has never sustained a due process challenge to the retroactive application of an income tax," that such a permissive standard relied on two conditions: first, that the amount to be paid be a tax and not a penalty; and second, that the period of retroactivity be brief. ${ }^{124}$ As to the first condition, the Ninth Circuit determined that, contrary to the Tax Court holding, ${ }^{125}$ the case involved a penalty, not an "addition to tax" as alleged by the government. ${ }^{126}$ As to the second condition, the court found that the period of retroactivity was "far longer than required simply by the practicalities of producing national legislation." 127

120. Id.

121. Licari, 946 F.2d at $694-95$.

122. Id. at 694.

123. Id. (citing Lawrence Zelenak, Are Rifle Shot Transition Rules and Other Ad Hoc Legislation Constitutional?, 44 TAX L. REV. 563, 608-09 n.224 (1989)).

124. Id. (citing United States v. Darusmont, 449 U.S. 292, 298 (1981)).

125. 58 Tax Ct. Mem. Dec. (CCH) 1119, 1126 (1990).

126. Licari, 946 F.2d at 691.

127. Id. at 694 . 
These findings required application of the general deference doctrine's rationality standard for review of retroactive economic legislation generally, ${ }_{128}$ rather than the tax deference doctrine's even more deferential (if possible) standard for review of retroactive tax legislation. ${ }^{129}$ Applying the general deference test, the court held that the retroactive penalty was a rational measure because it guards the public fisc by reimbursing the government for the cost of investigating and prosecuting tax underpayments, and because it "benefits the public revenue by encouraging those taxpayers with whom the IRS. has made no previous contact to amend tax returns that understate their income so that the IRS. will - waive the penalty." 130 However, despite its assertion that these rationales alone satisfied the general deference test, the court nonetheless proceeded to justify the law by applying the "alternative test for assessing retroactivity,"131 that is, the tax deference test set forth by the Supreme Court in Welch v. Henry ${ }^{132}$ requiring a court to consider "the nature of the tax and the circumstances in which it is laid." 133 By applying this "alternative" test, previously reserved for tax legislation, to a penalty the court had already explicitly found was not a tax, the Ninth Circuit revealed its uncertainty as to which test to apply and how to satisfy its requirements. ${ }^{134}$

Significantly, it was in the context of employing the tax deference standard that the court set forth two more reasons for the reasonableness of its decision. First, stating that the period of

128. Recall that the general deference doctrine only requires a court to find that the "retroactive application of the legislation is ... justified by a rational legislative purpose." Pension Benefit Guar. Corp. v. R.A. Gray \& Co., 467 U.S. 717, 730 (1984).

129. That is, the "nature and circumstances" test of the tax deference doctrine. See supra text accompanying notes 84-85.

130. Licari, 946 F.2d at 695 .

131. Id.

132. 305 U.S. 134 (1938).

133. Id. at 147; see supra text accompanying notes 79-90.

134. The decision to analyze the penalty under both standards is particularly unusual when one considers that the general deference test initially applied by the court is ostensibly the more difficult to satisfy, and thus the more deferential tax standard subsequently employed by the court would necessarily be similarly satisfied. Although it is possible that the court was merely trying to insulate its ruling from subsequent review by applying both standards, the court never explaimed its decision in this manner. Rather, the opinion suggests that the court considered the two doctrines to be interchangeable, an unusual holding in light of the court's previous remarks that retroactive tax legislation deserves "extremely weighty" deference while other economic lcgislation deserves "strong" deference. Licari, 946 F.2d at 694. 
retroactivity was a significant, but not determinative, factor of the law's validity under the tax deference standard, the court ratified the four-year length of the retroactivity period, citing two other cases upholding tax laws that applied for similarly long retroactivity periods: Canisius College v. United States ${ }^{135}$ and Temple University $v$. United States. ${ }^{136}$ These cases are distinguishable from Licari, however, for they involved curative legislation adopted in 1984 that applied retroactively to validate Federal Insurance Contributions Act (FICA) taxes that the Supreme Court had undermined in a 1981 decision. ${ }^{137}$ In other words, the laws in Canisius and Temple sought to preserve congressional intent, ${ }^{138}$ not to alter a previous law as was the case with the increased penalty in Licari. In view of the Ninth Circuit's misplaced reliance on these prior cases, it is evident that the court upheld an unprecedented period of retroactivity.

Turning to its other rationale, the court considered it significant that the Licaris had known they were acting contrary to law:

Here, we are not presented with a case in which an individual acted in accordance with the law as it stood at the time only later to be subjected to a penalty; instead, those subjected to the increased penalties, like the Licaris, knew at the time that they filed their returns that they were not acting in accordance with the law and could be subjected to a fine. They also knew that their unlawful actions would force the government to incur considerable costs in connection with the investigation and prosecu-

135. 799 F.2d 18, 26-27 (2d Cir. 1986), cert. denied, 481 U.S. 1014 (1987).

136. 769 F.2d 126, 134-35 (3d Cir. 1985), cert. denied, 476 U.S. 1182 (1986).

137. The Supreme Court in Rowan Cos. v. United States, 452 U.S. 247 (1981), disturbed a long-held IRS position with respect to FICA taxes, thereby allowing taxpayers with open tax years to sue to obtain refunds. Taking issue with Rowan, Congress codified the IRS position in 1983. In order to prevent the government's exposure to refund claims in 1984, Congress enacted a law applying the previous year's codification, enabling it to reach back almost five years to 1979. Canisius, 799 F.2d at 21-24.

138. Canisius, 799 F.2d at 27 ("In light of its curative purpose, we find the provision constitutional notwithstanding the long period of retroactivity."); Temple, 769 F.2d at 134 ("[W] application is typically entitled to be liberally construed."). Determining when a law is actually "curative" and when its retroactive effect is unconstitutional has received little treatment by the Court. In particular, the Court in Van Emmerik v. Janklow, 454 U.S. 1131 (1981), declined the invitation to "define the boundary between permissible and impermissible retroactive tax increases" imposed by curative legislation, instead dismissing the case for want of a substantial federal question. Id. at 1133-34 (White, J., dissenting from the dismissal). 
tion of their offense. Under these circumstances, we do not find imposition of the increased penalty unduly "harsh and oppressive." 139

In Usery v. Turner Elkhorn Mining Co. ${ }^{140}$ however, the Supreme Court had refused to entertain such a theory of blameworthiness as a rational basis for upholding a retroactive law. ${ }^{141}$ Admittedly, Turner Elkhorn involved conduct that the law had not yet deemed "wrongful" enough to impose liability, whereas Licari involved conduct that was already deemed wrongful, and only the degree of the punishment for such conduct was at issue. Yet despite this distinction, the element of blame is still inappropriate as a justification for the penalty in Licari, for there is no scienter involved in substantial understatement. ${ }^{142}$ As the penalty can be assessed even if the taxpayer does not know that he has violated the section, blameworthiness is not a necessary component. Therefore, although blameworthiness might be relevant to an offense that required knowledge, such as fraud under section $6653,{ }^{143}$ it does not seem a valid consideration when knowledge is not a required element of the violation.

Arguably, the desire to prevent people from understating their taxes is another possible congressional rationale, ${ }^{144}$ but this is a deterrence-based rationale that can operate only on a prospective basis. ${ }^{145}$ There can be no deterrence when there is no knowledge of the applicable penalty; and this principle lends support to the Supreme Court's disapproval in Turner Elkhorn of a deterrence theory for justifying retroactivity. ${ }^{146}$

139. Licari, 946 F.2d at 695 .

140. 428 U.S. 1 (1976); see supra text accompanying notes 46-48.

141. 428 U.S. at $17-18$.

142. As explained in the Senate Report on $\$ 6661$, these understatements involve "questionable (although non-negligent) positions not amounting to fraud or negligence . . ." Licari, 946 F.2d at 692 n.4 (quoting 1982 U.S.C.C.A.N. at 1019-20).

143. A separate penalty, to which the Licaris were also subjected, exists for fraudulent underpayment of taxes pursuant to I.R.C. § 6653. Licari, 946 F.2d at 691 n.1.

144. This point was raised by the Tax Court but was not explicitly discussed by the Ninth Circuit. See 58 Tax Ct. Mem. Dec. (CCH) 1119, 1126 (1990).

145. One might argue that if people know that penalties can be increased in the future and applied retroactively, then the result is prospective deterrence. However, it is hard to see how such a rationale could be limited in such a way as not to justify retroactivity on a disconcertingly broad scale.

146. 428 U.S. at $17-18$. 
The Ninth Circuit's failure to justify the penalty's lengthy retroactivity period and its questionable reliance on blameworthiness causes the validity of the retroactive penalty to rest inevitably on the court's fisc-guarding and revenue-raising rationales. Importantly, the legislative history of section 6661 suggests that the retroactive raising of the substantial understatement penalty by $150 \%$ occurred not out of a need for greater compliance but out of a desire to raise money. ${ }^{147}$ As one commentator has asserted, "It is doubtful that this kind of geometric increase in severity [from a $10 \%$ penalty to $25 \%$ ] can be justified based on compliance needs-nor was there even much pretense in that direction at the time of the last increase [in 1986]. It was a revenue raiser in a budget reconciliation." 148

Ultimately, although assessing a penalty retrospectively is certainly a rational means of raising revenue to reimburse the government, the real issue is whether it is rational to accept the government's desire for reimbursement as adequate justification for allowing retroactive application. ${ }^{149}$ In essence, the Ninth Circuit relied on rationales offered to justify the heightened penalty itself to justify its retroactive effect.

Notably, another circuit confronted with a comparable situation explicitly rejected the reasonableness of a revenue-raising rationale for retroactivity. In Nieves $v$. Hess Oil Virgin Islands

147. Section 6661 was originally conceived as a low rate (about $5 \%$ ), "no fault" audit charge to provide a "downside" cost for any noncompliance. Largely for revenue reasons, however, the penalty was imposed at $10 \%$. Ironically, the negligence penalty at that time was only $5 \%$, and thus this penalty was, from a compliance standpoint, either too high or the negligence penalty was too low if the penalty was to reflect the severity of the noncompliant behavior. Because the penalty bears nondeductible interest from the due date of the return, the retroactive increase of the penalty to $20 \%$, then $25 \%$, could easily increase the cost of inadvertent or even good-faith noncompliance to well over $35 \%$ if the penalty were assessed at the end of the three-year limitations period. Review of the Civil Penalty Provisions Contained in the Internal Revenue Code: Hearings Before the Subcomm. on Oversight of the House Comm. on Ways and Means, 100th Cong., 2d Sess. 223 (1988) (statement of Kenneth W. Gideon, former chief counsel, Internal Revenue Service).

148. Id.

149. The Supreme Court in Turner Elkhorn seemed to suggest the questionable propriety of a revenue-raising rationale when it took the opportunity to explain that "[t]he point of the black lung benefit provisions is not sinply to increase or supplement a former employee's salary to meet his generalized need for funds. Rather, the purpose of the Act is to satisfy a specific need created by the dangerous conditions under which the former einployee labored . . . " 428 U.S. at 19. 
Corp. ${ }^{150}$ the Third Circuit addressed a Contract Clause challenge to a workers' compensation law enacted by the Virgin Islands legislature that retroactively eliminated application of the "borrowed employee" doctrine $e^{151}$ as a bar to pending tort suits. Although it scrutinized the law under the Contract Clause, the court utilized a deferential standard of rationality that it compared to the standard in a due process context. ${ }^{152}$ The court held that

[e]ven under the deferential standard, if recouping past expenditures could justify a retroactively established cause of action the circumscription of the Contract Clause would be rendered practically meaningless. Almost any arrangement would then be subject to impairment in order to benefit a potentially faltering or floundering fund. While the need to keep the workmen's compensation fund on a sound financial basis may justify prospective legislation designed for that purpose, it cannot justify this type of retrospective legislation. ${ }^{153}$

Applying the minimum rationality standard in a manner that legitimates such revenue-raising rationales effectively eviscerates the test, rendering retroactive laws as readily sustainable as prospective legislation. ${ }^{154}$

Faced with an opportunity to apply this gutted minimum rationality standard only a year later in Carlton $v$. United States, ${ }^{155}$

150. 819 F.2d 1237 (3d Cir.), cert. denied, 484 U.S. 963 (1987).

151. The common law "borrowed employee" doctrine allows a company that is simply "borrowing" a worker employed by another company to be considered an "employer" of the borrowed employee for purposes of preventing such worker from suing the borrowing company for any mjuries he sustains; as a result, the borrowed employee's exclusive remedy is under the relevant workers' compensation act. Id. at 1240.

152. Id. at 1249.

153. Id. at 1251-52.

154. The illegitimacy of justifying retroactivity through a revenue-enhancing rationale has been searingly noted by Jim Gould, former Chief Counsel to the Senate Finance Committee, in his article on targeted retroactive taxes:

The specific new concept that we have before us is the targeted retroactive tax, or TRT. A TRT is a tax that raises revenue retroactively from a politically disfavored segment of society.

....

... It is true that the TRT concept could breed some distrust of the government and that it may be unfair by traditional standards. Certainly it may raise annoying constitutional questions. But those are frivolous reasons to ignore so rich a revenue-raising idea.

Jim Gould, A New Fiscal Bonanza in Tax Policy: The Targeted Retroactive Tax-TRT, 51 TAX NOTES 117, 117-18 (1991).

155. 972 F.2d 1051 (9th Cir. 1992), petition for reh'g filed, Sept. 29, 1992. 
the Ninth Circuit switch-hit and formulated a new two-part test for due process review more sympathetic to the rights of the taxpayer. In striking down the retroactive removal of a tax deduction provision, the Carlton majority has halted the sub silentio burial of due process and has forced a reconsideration of the constitutionality of retroactivity.

\section{B. The Wild Pitch: Carlton v. United States}

In the Tax Reform Act of 1986 (TRA), Congress sought to encourage the ownership of corporations by their employees by enacting section 2057, a provision adding a favorable estate tax deduction of up to fifty percent of a decedent's gross estate for the proceeds of a sale of a company's securities to its Employee Stock Ownership Plan (ESOP). ${ }^{156}$ This deduction was available to any estate that could timely file its return after the TRA's October 1986 enactment date, regardless of the date of the decedent's death. ${ }^{157}$ Jerry Carlton, an estate executor, after reviewing section 2057 and noting the beneficial effects of the new ESOP proceeds deduction, purchased in December 1986 qualifying shares of MCI worth over $\$ 11$ million and then sold the shares to the MCI ESOP at a discount. Carlton then timely filed an estate tax return deducting over $\$ 5$ million from the gross estate pursuant to section 2057. However, in January 1987, the IRS announced that pending the enactment of clarifying legislation, it would not recognize a section 2057 deduction unless the decedent had "directly owned" the securities before death. ${ }^{158}$ Congress subsequently passed legislation incorporating this decedent ownership requirement in December 1987 and made the amendment retroactively effective as of the date of the original passage of section 2057 in October 1986. ${ }^{159}$ In accordance with section 2057 as amended, the IRS rejected Carlton's ESOP proceeds deduction and determined a deficiency owed by the estate of over $\$ 3$ million. The district court regarded the retroactive application of the amend-

156. See I.R.C. \& 2057 (1988) (repealed 1989).

157. Carlton, 972 F.2d at 1053 (citing I.R.C. $\$ 2057$ (c)(1) (repealed 1989)).

158. Notice 87-13, 87-1 C.B. 432, 442 (1987).

159. See Act of Dec. 22, 1987, Pub. L. No. 100-203, \$ 10411, 101 Stat. $1330-432$ to 433 (repealed 1989). 
ment as not violative of due process because it did not impose a "wholly new tax."

On appeal, the Ninth Circuit in a 2-1 decision reversed the lower court's ruling, the first such invalidation of a retroactive tax law by any circuit in almost half a century. ${ }^{161}$ The majority "reject[ed] the notion of a per se rule that tax statutes can always be retroactively applied so long as they do not enact a 'wholly new' tax, ${ }^{, 162}$ asserting instead that

[t]he Supreme Court's two most recent decisions regarding retroactivity challenges to tax statutes, Hemme ${ }^{163}$ and Darusmont, ${ }^{164}$ did not involve wholly new taxes. Despite that fact, the Court engaged in a thorough analysis of the circumstances of each retroactive application before making its determination of constitutionality. This clearly indicates that retroactive application of the tax laws is not "automatically" permitted so long as a wholly new tax is not involved. ${ }^{165}$

To replace the "wholly new tax" rule, the majority undertook an examination of Supreıne Court cases. It found that

two circumstances emerge as of paramount importance in determining whether the retroactive application of a tax is unduly harsh and oppressive. First, did the taxpayer have actual or constructive notice that the tax statute would be retroactively amended? Second, did the taxpayer rely to his detriment on the pre-amendment tax statute, and was such reliance reasonable? 166 $^{16}$

As to the first criteria, the court found that Carlton had had neither actual nor constructive notice. The IRS had not proposed the decedent ownership requireinent until January 1987 (the month after the transaction by Carlton), and the bill that included the

160. Carlton, 972 F.2d at 1055.

161. See Wheeler v. Commissioner, 143 F.2d 162, 168 (9th Cir. 1944) (striking down tax statute with retroactive application because two-year period of retroactivity not "a reasonable length of time"), rev'd on other grounds, 324 U.S. 542 (1945). However, the Supreme Court ruled that in fact, the tax was not retroactive, and thus reversed the Ninth Circuit's decision. Given this fact, Carlton is the first Circuit Court decision to strike down a retroactive tax law since Welch v. Henry, 305 U.S. 134 (1938).

162. Carlton, 972 F.2d at 1056.

163. United States v. Hemme, 476 U.S. 558 (1986).

164. United States v. Darusmont, 449 U.S. 292 (1981) (per curiam).

165. Carlion, 972 F.2d at 1056.

166. Id. at 1059. 
amendment had not been introduced in Congress until February 1987. Further, the court dismissed the government's assertion that the legislative history of the original legislation had given Carlton constructive notice that a decedent ownership requirement was "surely in the offing," calling such evidence "fleeting" and "ambiguous." 167 In short, the court found that "no act of the executive or legislative branch would have given any forewarning of the 1987 amendment at the time the MCI ESOP transaction occurred."168

As for whether Carlton had reasonably and detrimentally relied on section 2057 as enacted in 1986, the court concluded first, that specific reliance had already been stipulated to by the government; second, that such reliance had been reasonable in light of the plain language of the section and in the context of the huge tax incentives that Congress had created to encourage the development of ESOPs; and third, that such reliance had been detrimental to Carlton in the amount of $\$ 631,000$ (the loss that had been incurred in selling the shares back to the MCI ESOP at a discount-a "necessary concession to complete the deal"). ${ }^{169}$ In finding for Carlton, the court thus rejected the government's argument that section 2057 as originally enacted was a loophole that could not reasonably be relied on because it was a windfall "too good to be true." 170

In distinguishing Carlton from its earlier decision in Licari, the court offered the abrupt remark that the Licaris, unlike Carlton, had been blameworthy. ${ }^{171}$ This distinction, of questionable relevance, was coupled with another distinction: the concepts of constructive notice and detrimental reliance, asserted as the two para-

\footnotetext{
167. Id.

168. Id.

169. Id. at 1061. The court explained that

in practice the only way to have obtained the deduction was for the estate to offer to 'share' it with the other party necessary to the transaction, the ESOP ... . The MCl ESOP had to have some incentive to deal with Carlton, given the extra paperwork required, rather than just purchase its shares on the open market.
} Id.

170. Id. at 1060 ("We flatly reject the government's premise that a taxpayer cannot rely on the clear and unequivocal text of the tax code, but instead must speculate on the unspoken and imchoate intentions of Congress."). The court also rejected the government's assertion that Carlton's transaction was a sham, holding that the permanently changed positions of the parties showed that the transaction was real and had substance. Id. at 1061-62.

171. Id. at 1058-59. 
mount criteria to be examined, had not even been discussed in the Licari opinion. Indeed, there was no evidence that the Licaris had had notice of the retroactive tax penalty at issue when filing their returns, and yet the Licari court never considered this to be pertinent, let alone controlling. ${ }^{172}$ Moreover, whereas the Licari court had not been offended by Congress's extension of the retroactivity period to the time when the original law was passed almost four years earlier, the majority in Carlton was unwilling to allow Congress to repeat this conduct and apply the amendment retroactively to the date of the ESOP deduction's initial enactment-only slightly more than a year earlier.

The validity of the majority's two-part test was challenged by Judge William Norris, who asserted in dissent that "[w]hile maximum fairness to taxpayers might argue that Congress should legislate according to this generous standard, the Supreme Court has declined to adopt it as a requirement of Due Process." 173 In particular, Judge Norris argued that the Supreme Court has explicitly questioned the relevancy of constructive notice and detrimental reliance when reviewing retroactivity. ${ }^{174} \mathrm{He}$ reasoned that the Lochner era Supreme Court cases that had invalidated retroactive gift and estate taxes ${ }^{175}$ had been limited either to their facts or to the retroactive imposition of a wholly new tax, and that a retroactive change in the base or rate of an existing tax did not violate due process. ${ }^{176}$ Thus, constructive notice to the taxpayer is implied for any alteration of an existing tax, for income taxation is a "matter of legislative grace ... within the power of Congress to revoke" retrospectively. ${ }^{17}$

172. That the Licaris lacked constructive notice is augmented by the fact that the retroactive increase of the tax penalty in their case appears to have been the first time that a tax penalty was ever raised retroactively. John A. Corry, Retroactive Penalties Raise Constitutional Issues, 36 TAX NOTES 723, 726 (1987) ("An even stronger basis for challenge on due process grounds is the totally unexpected nature of the retroactive aspect of this legislation [ $\$ \S 6656$ and 6661 ]. I have found no cases in which penalties have been increased retroactively rather than prospectively.").

173. Carlton, 972 F.2d at 1065 (Norris, J., dissenting).

174. Id. at' $1063-65$.

175. The dissent specifically referred to the following three cases: Untermyer v. Anderson, 276 U.S. 440 (1928); Blodgett v. Holden, 275 U.S. 142 (1927); Nichols v. Coolidge, 274 U.S. 531 (1927). For an examination of these cases as they relate to the evolution of the tax deference doctrine, see supra text accompanying notes 70-76.

176. Carlton, 972 F.2d at 1064 (citing Fein v. United States, 730 F.2d 1211, 1213 (8th Cir.), cert. denied, 469 U.S. 858 (1984)); Estate of Ekins v. Commissioner, 797 F.2d 481, 483 (7th Cir. 1986) (citing Milliken v. United States, 283 U.S. I5, 23 (1931)).

177. Carlion, 972 F.2d at 1064 (citing Miller v. Commissioner, 115 F.2d 479, 480 (9th 
Furthermore, the dissent noted that the Supreme Court has specifically questioned (although not decided) whether notice is even a relevant inquiry when reviewing the retroactivity of any type of economic legislation. ${ }^{178}$ Thus, according to the dissent, the majority's factual analysis as to the taxpayer's constructive notice was off-base, either because this element was immaterial or because the retroactive amendment was merely abolishing, that is, "altering," an existing ESOP deduction. Furthermore, the dissent noted that the year-and-two-month retroactivity period was well within the boundaries of permissible retroactivity. ${ }^{179}$

\section{The Squeeze Play: Lessons from Licari and Carlton}

Licari and Carlton legitimately raise challenges to the continuing validity of three fundamental concepts in retroactivity adjudication: first, that retrospective tax statutes should be provided with greater judicial deference than any other type of economic legislation (the tax deference versus the general deference doctrine) $;{ }^{180}$ second, that the "minimum rationality" standard used to determine the constitutionality of prospective economic legislation should be equally applicable when courts examine the retroactive effect of economic measures; ${ }^{181}$ and third, that this minimum rationality standard, which underlies both the tax deference and general deference doctrines, adequately addresses the due process concerns attending retroactive legislation. The Ninth Circuit's unsatisfactory reconciliation of the two doctrines in Licari and Carlton demonstrates the squeezing of the minimum rationality standard between two decisions that allow the court to switch-hit depending on its sympathies.

Cir. 1940)).

178. Id. at 1065 (citing United States v. Darusmont, 449 U.S. 292, 299 (1981) (per curiam)); cf. Pension Benefit Guar. Corp. v. R.A. Gray \& Co., 467 U.S. 717, 731-32 (1984) ("We have doubts, however, that retroactive application of the MPPAA would be invalid under the Due Process Clause for lack of notice even if it was suddenly enacted by Congress without any period of deliberate consideration .....").

179. Carlton, 972 F.2d at $1064-65$ (citing Darusmont, 449 U.S. at 296). The dissent also argued that even if it were to apply the majority's test, it would have upheld the law because the decedent ownership requirement was implicit from the legislative history and because the statute "offered a benefit that appeared too good to be true." Id. at 1065-66 (Norris, J., dissenting).

180. See Licari v. Commissioner, 946 F.2d 690, 694 (9th Cir. 1991).

181. See id. 
Perhaps the most significant consequence of the decisions is the implicit reversal in deference that emerges. Although the Supreme Court has suggested that tax laws are to be examined with greater deference than other retroactive economic laws, ${ }^{182}$ the majority in Carlton has implemented a tax deference test that is actually facially stronger than the "mere rationality" analysis used under the general deference doctrine. Whereas the test used to examine the constitutionality of retroactive economic legislation seems to require courts to consider only whether the legislation is rationally related to a legitimate governmental interest, ${ }^{183}$ the due process analysis set forth in Carlton demands that a court also examine the issues of notice and detrimental reliance. The practical effect of this distinction is to subject tax laws to a more stringent examination, despite the Supreme Court's contention that retroactive tax laws are less offensive to due process than other retroactive economic legislation. In Licari, the Ninth Circuit was content to follow the literal language of the general deference doctrine and examine only whether the retroactive penalty was rational. The court did not consider the voluntariness of the Licaris' conduct or determine whether they would have acted differently had they been aware of the heightened punishment. ${ }^{184}$ Nor did

182. See supra notes $80-100$ and accompanying text.

183. Recall that the general deference doctrine requires courts to determine whether "the retroactive application of the legislation is itself justified by a rational legislative purpose." Pension Benefit Guar. Corp. v. R.A. Gray \& Co., 467 U.S. 717, 730 (1984). The absence of any "nature or circumstances" language in this command has led the Supreme Court in subsequent decisions to concentrate only on the rationality of the retroactivity. For example, in General Motors Corp. v. Romein, 112 S. Ct. 1105, 1112 (1992), the Supreme Court dismissed a due process challenge to a retroactive economic law by asserting that it was rational for the state legislature to want to cure retroactively an unexpected judicial interpretation of a law. Notably, the Court did not engage in any examination of notice or detrimental reliance as done by the majority in Carlion. Similarly, the Court in United States v. Sperry Corp., 493 U.S. 52 (1989), upheld the retroactive imposition of a claims tribunal fee because the Court considered it rational for the legislature to want to require everyone who used the tribunal to have to pay a fee for its services. Id. at 64-66. Again, the Court did not examine notice or reliance issues. Thus, in its recent cases that have einployed the general deference doctrine, the Court has almost strictly applied the rational relation test without considering many of the factors that have proved pertinent inquiries in the tax context. Moreover, this has occurred despite the Court's earlier treatment (however cursory) of these types of issues in both Pension Benefit and Turner Elkhorn. See Pension Benefit, 467 U.S. at 731-32 (questioning whether advance notice of legislative action with retrospective effects is constitutionally compelled); Usery v. Turner Elkhorn Mining Co., 428 U.S. 1, 17 (1976) (discussing relevance of a party's reliance on prior law).

184. Whether the Licari court's discussion of blameworthiness implicitly incorporates 
the court examine whether the Licaris had had notice of the retroactive change. In contrast, the majority in Carlton spent considerable time examining the issues of notice and reliance, even though it was analyzing a tax law that ostensibly received greater deference than the economic law that was present in Licari. Ironically, this inapposite result is a natural consequence of the Supreme Court's confusing articulation of the tax deference and the general deference doctrines. Whereas the "nature and circumstances" standard of the tax deference doctrine suggests an inquiry that examines more than the rationality of the legislative purpose of the tax law, the "rational relation" standard of the general deference doctrine suggests an inquiry that examines only the rationality of the legislative purpose. This tension between theory (tax laws deserve greater deference) and reality (tax laws are more heavily scrutinized) makes apparent the need to abandon the tax/non-tax distinction altogether in favor of a single standard of review that avoids this internal conflict.

In many ways, the majority in Carlton has forced the Supreme Court's hand; it is challenging whether retroactive legislation, either tax or economic, can offend due process despite the formidable record of unsuccessful challenges on this ground. Although the Supreme Court may disagree with the Carlton majority's two-part test, it is difficult to disagree with the Carlton majority's characterization that Congress created an incentive and then dismantled it after the fact because it was dissatisfied (and surprised) with the result. ${ }^{185}$ The very fact that a dissenting member of the court argued that Congress does have the power to engage in this sort of legislative "tinkering" compels a study of the theories underlying

the notion of voluntariness is unclear. More likely, the blameworthiness argument merely implicates an "unclean hands" rationale commonly used in equitable analyses.

185. See Carlion, 972 F.2d at 1060 ("Then, when the private actor had completed the socially desirable action of selling shares at a discount to an ESOP, the government reneged on its end of the deal."). As one commentator has remarked, Carlton "suggests that Congress and the IRS should be bound by the tax laws they have written to the same extent that the laws bind taxpayers." Jerry A. Kasner, The Amendment of Section 2507 Was Unconstitutional, 92 TNT 207-78; $c f$. Temple Univ. v. United States, 769 F.2d 126, 139 (3d Cir. 1985) (Weis, J., dissenting):

I see no need for the court to be unduly solicitous about curing statutory deficiencies to aid the IRS in doubtful cases. The Service insists on adherence to the technical requirements of the Code when convenient. That approach is not improper, but the same rule should apply when it is the taxpayer who benefits. He who lives by the sword of rigid adherence to technicalities should not be surprised at being nicked in return from time to time. 
the tax deference and general deference doctrines to determine the scope of a legislature's powers to enact and amend laws retroactively.

\section{THE Rules OF THE GAME: REeXAMINING THE HOW AND WHY OF RETROACTIVITY REVIEW}

A distillation of the competing justifications relied on by courts to permit the retroactive application of economic legislation reveals the absence of any consensus as to the proper approach to reviewing due process challenges. The difficulty in defining the proper approach to due process review derives from the perpetuation of the tax/non-tax distinction ${ }^{186}$ and the vague, and perhaps deceptive, language that the Supreme Court has employed under both the tax deference and general deference standards. ${ }^{187}$ The superficial differences between these two standards and their continued separate treatment have obscured the fact that courts have, in practice, often scrutinized retroactive tax laws and other economic laws through equivalent lenses that have focused interchangeably on notions of equity, notice, voluntariness, reliance, and impact (that is, the cost to the citizen of the retroactive laws). A study of the body of caselaw that preceded the Welch Court's enunciation of the tax deference doctrine in Section $A$ and a survey of the different bases for examining both retroactive tax and economic laws in Section B offer insight into the factors that should ultimately control due process review of economic retroactivity.

\section{A. Relegating Taxes to the Dugout: The Making of a Myth?}

Modern constitutional doctrine on retroactive tax legislation relies in part on a series of pre-Welch cases supporting the proposition "that the application of an income tax statute to the entire calendar year in which enactment took place does not per se violate the Due Process Clause of the Fifth Amendment."188 Al-

186. The tax/non-tax distinction has artificially tied the proper level of scrutiny to an initial determination of whether a law is a tax or not (as arose in Licari) and has sired caselaw that remains in conflict over the appropriate criteria to consider. See infra Section III(B).

187. See supra text accompanying notes 182-85.

188. United States v. Darusinont, 449 U.S. 292, 297 (1981) (per curiam) (citing Stockdale v. Insurance Cos., 87 U.S. (20 Wall.) 323, 331-32 (1874)); United States v. 
though the cases do stand for that proposition, they never articulate the reasoning behind the proposition. With the significant extension of permitted retroactivity to tax legislation outside the income tax realm, the foundations of modern tax retroactivity doctrine are due for reexamination.

The earliest case cited by the Supreme Court in United States v. Darusmont ${ }^{189}$ as justifying the retroactive application of tax legislation was the 1874 case of Stockdale v. Insurance Companies. ${ }^{190}$ In Stockdale, the Court upheld the retroactive effect of an income tax on corporate dividends as a "legitimate exercise of the taxing power by which a tax, which might be supposed to have expired, was revived and continued in existence for two years longer." ${ }^{191}$ The Darusmont Court quoted the following passage from Stockdale as evidence of the clear permissibility of retroactivity in the tax arena:

The, right of Congress to have imposed this tax by a new statute, although the measure of it was governed by the income of the past year, cannot be doubted; much less can it be doubted that it could impose such a tax on the income of the current year, though part of that year had elapsed when the statute was passed. ${ }^{192}$

Importantly, the Stockdale Court had failed to cite a single authority to support this proposition. Moreover, in the subsequent paragraph of its decision, the Court had offered the following comment:

Both in principle and authority it may be taken to be established, that a legislative body may by statute declare the construction of previous statutes so as to bind the courts in reference to all transactions occurring after the passage of the law, and may in many cases thus furnish the rule to govern the courts in transactions which are past, provided no constitutional right of the party concerned is violated. ${ }^{193}$

Hudson, 299 U.S. 498, $500-01$ (1937); Reinecke v. Smith, 289 U.S. 172, 175 (1933); Milliken v. United States, 283 U.S. 15, 21 (1931); Cooper v. United States, 280 U.S. 409, 411 (1930); Brushaber v. Union Pac. R.R., 240 U.S. 1, 20 (1916).

189. 449 U.S. 292 (1981) (per curiam).

190. 87 U.S. (20 Wall.) 323 (1874).

191. Id. at 333 .

192. Id. at 331, quoted in Darusmont, 449 U.S. at 297.

193. Stockdale, 87 U.S. at 331. 
Although allegedly asserting a well-grounded principle, the Stockdale Court had cited only one case to defend this position: a Louisiana case, Municipality No. 1 v. Wheeler. ${ }^{194}$ In Wheeler, the Louisiana Supreme Court had remarked: "However repugnant to logic and sound policy they may be, retrospective laws in civil matters do not violate the Constitution, unless they tend to divest vested rights or to impair the obligation of contracts ...."195 But the Louisiana court neither offered a single policy rationale for such a rule of law nor referred to any decisional law or AngloAmerican treatise on the subject. ${ }^{196}$ Thus, the sole precedential support for the Stockdale holding was an unsubstantiated Louisiana Supreme Court opinion that had explicitly recognized the illogic and unsoundness of retroactive laws and implicitly questioned the appropriateness of extreme judicial deference to such legislation.

The absence of precedential support in the Wheeler opinion had not necessarily rendered that decision unpersuasive. However, when a court states that a rule is illogical and irrational, it should at least cite to precedent to explain its continued adherence to the rule. The Wheeler court plainly did not rely upon common sense and reason. Limiting the application of the Due Process Clauses to violations of vested rights greatly narrows the scope of possible judicial review of retroactive civil laws. ${ }^{197}$ Moreover, the vested rights analysis has fallen into disfavor, as courts and commentators have recognized its conclusory nature-a right is vested only when it cannot be taken away by statute. ${ }^{198}$

194. 10 La. Ann. 745 (1855).

195. Id. at 745.

196. The Wheeler court did, however, cite to a French excerpt from Marcade $\S 62$.

197. Carrying the vested rights reasoning in Wheeler to its logical ends would result in the Court's inability to strike down any retroactive tax law affecting an already established tax, for as the Court asserted in Darusmont, no person can ever have a vested right in a tax rate. United States v. Darusmont, 449 U.S. 292, 298 (1981). It follows, then, that since changes to existing tax laws could in one way or another be deemed to be changes in rates, no person could ever have a vested right in taxation generally. Such inviolability is certainly undesirable-it would make all retroactive tax laws immune from judicial review-and the Supreme Court refused to adhere to this result when it invalidated early gift and estate taxes.

198. Hochman, supra note 5, at 696 \& n.24; see also W. David Slawson, Constitutional and Legislative Considerations in Retroactive Lawmaking, 48 CAL. L. REV. 216, 251 (1960) ("To ask whether a law is vested-rights-retroactive ... is only to restate the question of its sufficiency in light of substantive due process. Vested-rights retroactivity is a superfluous category."). 
The infirmity of the Stockdale decision proves vitally significant, for of the subsequent cases cited by the Supreme Court in Darusmont, not one attempted to explain the justification for this "illogical and unsound" rule for retroactivity review. Rather, each case cited its predecessor cases as sufficient proof of the rule's validity. In Brushaber v. Union Pacific Railroad, ${ }^{199}$ the Court without comment cited to Stockdale as having settled any contention that retroactive tax laws violate due process. Similarly, in Lynch v. Hornby, ${ }^{200}$ Cooper v. United States, ${ }^{201}$ Milliken v. United States, ${ }^{202}$ Reinecke v. Smith, ${ }^{203}$ and United States v. Hudson, ${ }^{204}$ the Court reaffirmed the propriety of the retroactive taxes at issue only through caselaw that had its founding in Stockdale. Moreover, the two law review articles to which the Darusmont Court refers as implicitly supporting the validity of the tax deference doctrine did not defend or approve of the doctrine, but rather attempted merely to clarify its development and application. ${ }^{205}$ Thus, the Darusmont Court's invocation of pre-Welch precedent as justification of the extra deference accorded retroactive tax legislation exposes a history of caselaw that often asserted, but did not articulate the rationales for, the propriety of such deference.

This weak historical assertion of tax legislation's special retroactive status finds further expression in the Welch Court's oft-quoted statement that no citizen enjoys immunity from taxation because " $[t]$ axation is neither a penalty imposed on the taxpayer nor a liability which he assumes by contract . . . but a way of apportioning the cost of government among those who in some measure are privileged to enjoy its benefits and must bear its burdens."206 The initial appeal of this passage, with its implicit analogy to a "birth, death, and taxes" rationale, belies its emptiness. It would be as true to say that the bearing of the cost of the Iran-United States Claims Tribunal in Sperry was neither a penalty imposed on

199. 240 U.S. 1,20 (1916).

200. 247 U.S. 339,343 (1918).

201. 280 U.S. 409,411 (1930).

202. 283 U.S. 15,21 (1931).

203. 289 U.S. 172,175 (1933).

204. 299 U.S. $498,500-01$ (1937).

205. See Frederick A. Ballard, Retroactive Federal Taxation, 48 HARV. L. REV. 592 (1935); Hochman, supra note 5, at 706-11. In fact, Professor Ballard specifically remarked in his article that he "has not concerned himself" with "the justice and expediency of retroactive taxes." Ballard, supra, at 619.

206. Welch v. Henry, 305 U.S. 134, 146-47 (1938). 
the taxpayer nor a liability imposed by contract, but rather a way of apportioning the costs of the Tribunal among the citizens of the United States who Congress believed rationally should bear them. ${ }^{207}$ Although the penalty in Sperry applied only to those persons who actually utilized the Tribunal, so the retroactive dividends tax in Welch affected only those citizens who chose to invest in the dividend-paying securities at issue. Citizens who did not hold such investments were, in fact, immune from the burden imposed by the tax. Thus, despite the Court's assertion of tax legislation's uniqueness, other economic legislation can fall under its rubric by virtue of their similar apportioning of the costs of government among the citizenry. This fact, coupled with the selfserving reasoning of the cases preceding Welch, undermines the legitimacy of the tax/non-tax distinction and supports adoption of a more uniform approach to all retroactive economic laws.

\section{B. Mixed Signals: A Retrospective on Retroactivity}

In the two lines of cases examining retroactivity in tax and economic legislation, the courts have forwarded a variety of rationales for the permissiveness of retroactivity. This array of different reasons has, in fact, caused much of the confusion in this field. Courts have based their holdings on grounds that include the duration of the retroactivity period, the existence or absence of adequate notice, and the distinction between voluntary and involuntary conduct. The Supreme Court's inconsistent and indeterminate reliance on these factors, and indeed its indifference to many of them, has fostered the cryptic caselaw that lower courts have had to reconcile.

1. Strike One? Short Periods of Retroactivity. With the single exception of Carlion, retroactivity periods of approximately two years or less have been uniformly sustained by federal courts. ${ }^{208}$

207. United States v. Sperry Corp., 493 U.S. 52, 64-65 (1989).

208. See supra note 109; see also Robinson v. Sullivan, 905 F.2d 1199, 1202 (8th Cir. 1990) (holding that two-and-a-half year retroactive application of an exemption for senior judges from the Social Security Act did not violate due process); Rhinebarger v. Orr, 839 F.2d 387 (7th Cir.) (holding that one-year period of retroactivity arising from amendment to Fair Labor Standards Act that stayed the effect of Supreme Court decision in Garcia v. San Antonio Metro. Transit Auth., 469 U.S. 528 (1985), allowing recovery of overtime compensation did not violate due process), cert. denied, 488 U.S. 824 (1988); accord Wheeler v. Commissioner, 143 F.2d 162 (9th Cir. 1944), rev'd on other grounds, 324 U.S. 
As the Supreme Court explained in Darusmont, the enactment of general revenue statutes with retroactivity periods "confined to short and limited periods required by the practicalities of producing national legislation ... is a customary congressional practice." ${ }^{209}$ Although this rule was introduced in the context of the tax laws, it was considered by the Court in Pension Benefit to apply to any retroactive economic statute. ${ }^{210}$ The rationale for the rule appears twofold: First, Congress has long regarded such practice as constitutional; and second, such practice is necessary for the effective operation of government.

a. "Customary congressional practice." The Court has noted that Congress has traditionally enacted legislation having short and limited retroactivity periods. ${ }^{211}$ However, such an emphasis on congressional practice, except as historical evidence of the intent of the framers of a constitutional provision, is misguided, for repetition of an abuse should not entrench it. Although it is reasonable for the Court to make note of Congress's interpretation of the Constitution, the Court should not allow the longevi-

542 (1945). In Wheeler, the Ninth Circuit struck down a retroactive tax that reached back about two years because the legislature had not enacted the law "within the next session of the legislature or within a reasonable length of time ..." 143 F.2d at 168. The Supreme Court reversed, stating that the new law merely clarified its predecessor, and therefore was not a retroactive law at all. 324 U.S. at 546, 548. Thus, although the Wheeler case was technically reversed on other grounds, the Ninth Circuit's invalidation has little precedential value and does not disturb the uniform rejection of due process challenges to two-year-or-less retroactivity periods.

209. United States v. Darusmont, 449 U.S. 292, 296-97 (1981) (per curiam).

210. In Pension Benefit, the Court stated:

As we recently noted when upholding the retroactive application of an income tax statute in United States $v$. Darusmont, the enactment of retroactive statutes "confined to short and limited periods required by the practicalities of producing national legislation . . . is a customary congressional practice." We are loathe to reject such a common practice when conducting the limited judicial review accorded economic legislation under the Fifth Amendment's Due Process Clause.

Pension Benefit Guar. Corp. v. R.A. Gray \& Co., 467 U.S. 717, 731 (1984) (citation omitted).

This abrupt Ieap from the tax to the non-tax arena is questionable given that the Court has in part predicated the acceptance of such short periods of retroactivity in the tax context on the presumption that necessary information regarding taxable events is unobtainable until well into the legislative year, and thus legislatures must await such information before revising the codes. See Welch, 305 U.S. at 150-51; see also infra text accompanying notes $214-25$.

211. Pension Benefit, 467 U.S. at 731; Darusmont, 449 U.S. at 296-97; Welch, 305 U.S. at 148. 
ty of a congressional practice to blind it to the possible unconstitutionality of the activity. ${ }^{212}$ Legislators are inherently self-interested when determining the scope of their powers; granting legislators the power to effectively validate their own actions conflicts with the central tenets of separation of powers and judicial review. Thus, customary congressional practice should not serve as a marker of legislative authority. ${ }^{213}$

b. Legislative necessity. The Supreme Court has further argued that allowing a legislature to enact laws having short and limited retroactivity periods is of legislative necessity. As noted by the Court in Welch, legislatures are generally unable to obtain information regarding the sources and amounts of various classes of taxable income from the previous year until well into the next year. ${ }^{214}$ To deny legislatures the ability to await such information and then implement taxes retrospectively based upon this knowledge constitutes an unreasonable interference with a necessary legislative practice. ${ }^{215}$

Although based on sound concerns, this legislative necessity rationale falters when applied beyond the narrow confines of its "presumption of unavailable information" reasoning. First, it does not necessarily follow that the license that legislatures receive to enact retroactive income tax laws applies equally to other laws. Economic laws generally do not require retroactive application in order to compensate for the time lost awaiting relevant information, since the laws often reflect knowledge that has been known for some time but has only recently been acted upon. ${ }^{216}$ It therefore seems unwarranted to expand prophylactically this "presump-

212. See, e.g., INS v. Chadha, 462 U.S. 919, 944-45 (1983) (holding legislative veto power used by Congress for over 50 years unconstitutional); Elrod v. Burns, 427 U.S. 347 (1976) (holding political patronage system practiced for over 185 years unconstitutional).

213. Moreover, while Congress's customary practice to enact tax laws retroactively may have relevance as to the argument that taxpayers are on constructive notice of such changes, this rationale sets no apparent limits. To argue that notice is served as to a retroactive tax law merely by the fact that Congress has done such activity in the past is to reduce the concept of notice to near meaninglessness. For further discussion of the issue of notice, see infra text accompanying notes $226-43$.

214. 305 U.S. at $150-51$.

215. Id.

216. See, e.g., Usery v. Turner Elkhorn Mining Co., 428 U.S. 1, 17 (1976) (in which the facts suggest that the deleterious effects of black lung disease were well known before enactment of the coal mining law at issue). 
tion of unavailable information" to all laws whose retroactivity periods are deemed by a court to be short and limited.

Second, the logic of the legislative necessity rationale necessarily diminishes as the retroactivity period increases. Although legislative necessity may support permitting taxes to be applied retroactively to the year of enactment, or even to the year preceding enactment, the four-year retroactivity period involved in Licari was not required because of the absence of information, but rather was simply an attempt to alleviate the nation's burgeoning budget deficit. ${ }^{217}$ In fact, the Ninth Circuit explicitly held that the fouryear period was "far longer than required ... by the practicalities of producing national legislation," 218 a conclusion which prompted the court to reject the application of the tax deference doctrine to the penalty at issue..$^{219}$

Finally, the concept of legislative necessity subsumes the controversial notion that the shorter the retroactivity period, the less offensive a statute is likely to be, since it is only upsetting "recent" (rather than long-held) past expectations. However, the higher tolerance for "short and limited" periods of retroactivity as compared to long periods of retroactivity is tenuous. How long must an expectation exist before it is considered "settled"? The Supreme Court has only spoken to this question in vague terms that merely acknowledge a tolerance for "recent transactions."220 Lower federal courts have similarly avoided this issue-not a single court of appeals has yet adopted an absolute temporal limitation on retroactivity. ${ }^{221}$ On a theoretical level, once a legitimate past expectation is disturbed, it is questionable whether the brevity of the expectation should even be a relevant concern and whether legislative necessity should outweigh even short-term expectations.

217. See supra notes $147-48$ and accompanying text.

218. Licari v. Commissioner, 946 F.2d 690, 694 (9th Cir. 1991).

219. Id.

220. Welch v. Henry, 305 U.S. 134, 150 (1938); Cooper v. United States, 280 U.S. 409, 411 (1930); cf. United States v. Hudson, 299 U.S. 498, 500 (1937) ("relatively short periods").

221. Temple Univ. v. United States, 769 F.2d 126, 135 (3d Cir. 1985) (citing Shanahan v. United States, 447 F.2d 1082, 1084 (10th Cir. 1971); First Nat'l Bank in Dallas v. United States, 420 F.2d 725, 730 (Ct. Cl.), cert. denied, 398 U.S. 950 (1970); Wilgard Realty Co. v. Commissioner, 127 F.2d 514, 517 (2d Cir.), cert. denied, 317 U.S. 655 (1942)). 
Nonetheless, as Justice Holmes said, "[A] page of history is worth a volume of logic."222 The tremendous precedential acceptance of short-period retroactivity, even if of questionable soundness, is perhaps too deeply rooted to disturb. ${ }^{223}$ As a result, the length of a law's retroactivity period has proved a useful factor for courts to consider. However, while the limited duration of a retroactivity period succeeds in sustaining a law's constitutionality, the converse has not been the case. ${ }^{224}$ Indeed, the short-period retroactivity rationale has in practice simply become a safe harbor-a means for upholding a retroactive law, but not a means for rejecting one. ${ }^{225}$ Limiting the rule in this manner has undercut the usefulness of this rationale as a device for preventing retroactivity, thus requiring resort to other rationales that might form a basis for attacking retroactive laws.

2. Strike Two? Adequate Notice. The importance of notice to an analysis of retroactive economic laws remains unclear. Whereas lower courts have frequently cited to the presence or absence of notice when determining the constitutionality of a retroactive law, ${ }^{226}$ the Supreme Court has persistently questioned or

222. New York Trust Co. v. Eisner, 256 U.S. 345, 349 (1921).

223. As stated by Justice Burger in a different context, "It is obviously correct that no one acquires a vested or protected right in violation of the Constitution by long use, even when that span of time covers our entire national existence and indeed predates it. Yet an unbroken practice ... is not something to be lightly cast aside." Walz v. Tax Commission, 397 U.S. 664, 678 (1970).

224. See, e.g., Licari v. Commissioner, 946 F.2d 690, 695 (9th Cir. 1991) ("The fouryear period of retroactivity raises some cause for concern; however, we do not believe that this, by itself, is sufficient to meet the "harsh and oppressive' test."). Other cases that have upheld laws with retroactivity periods of around three years or longer have justified such lengths as permissible because of the curative character of the legislation. See supra notes $135-38$ and accompanying text.

225. This is not to say that courts would tolerate any period of retroactivity. However, the period of time that would be necessary to so offend the courts remains elusive, and one might question whether such a period may ever arise.

226. See, e.g., Wiggins v. Commissioner, 904 F.2d 311, 314 (5th Cir. 1990) (noting that retroactive laws have been held unconstitutional only when they imposed a wholly new liability that was unanticipated and thus denied notice); Estate of Ekins v. Commissioner, 797 F.2d 481, 483-84 (7th Cir. 1986) (same); Fein v. United States, 730 F.2d 1211, 1213-14 (8th Cir.) (same), cert. denied, 469 U.S. 858 (1984); Westwick v. Commissioner, 636 F.2d 291, 292 (10th Cir. 1980) (same); Purvis v. United States, 501 F.2d 311, 314 (9th Cir. 1974) (holding that the taxpayer had adequate notice of the retroactive application of a tax on purchases by Americans of foreign securities because the period of retroactivity applied back only to the time when President Kennedy originally proposed the law), cert. denied, 420 U.S. 947 (1975); First Nat'l Bank in Dallas v. United States, 
ignored its relevance. ${ }^{227}$ In fact, much of the Supreme Court's contemporary discussion of notice has arisen from holdings in which the Court has only assumed arguendo that notice plays a material role. ${ }^{228}$ In such cases, the Court has been quick to accept the argument that the citizenry receives constructive (if not actual) notice of a pending change in the law by a retroactive provision's mere existence as a bill anywhere in the legislative process. ${ }^{229}$ This rationale relies on the importance of preventing alert citizens from exploiting the "window of opportunity" between the introduction of a bill and its eventual enactment. ${ }^{230}$ However, as Justice McReynolds explained in Untermyer v. Anderson, ${ }^{231}$ the future of every bill before Congress is "necessarily uncertain" until its final enactment, ${ }^{232}$ because bills are often changed or struck down during the legislative process. This difficulty is exem-

420 F.2d 725, 730-31 (Ct. Cl.) (same), cert. denied, 398 U.S. 950 (1970).

227. See, e.g., United States v. Sperry Corp., 493 U.S. 52, 64-65 (1989) (where Court did not engage in any examination of notice in upholding a retroactive fee imposed on the users of a claims tribunal); Pension Benefit Guar. Corp. v. R.A. Gray \& Co., 467 U.S. 717, 731-32 (1984) ("We have doubts, however, that retroactive application of the MPPAA would be invalid under the Due Process Clause for lack of notice even if it was suddenly enacted by Congress without any period of deliberate consideration . . . But even assuming that advance notice of legislative action with retrospective effects is constitutionally compelled, ... we believe that employers had ample notice of the withdrawal liability imposed by the MPPAA.") (citation omitted); United States v. Darusmont, 449 U.S. 292, 299 (1981) ("Assuming, for purposes of argument, that personal notice is relevant, appellee is hardly in a position to claim surprise at the 1976 amendments to the minimum tax."). But see United States v. Hemme, 476 U.S. 558 (1986), where the Court appeared to acknowledge the relevance of notice in holding that "[o]ne of the relevant circumstances is whether, without notice, a statute gives a different and more oppressive legal effect." Id. at 569 (emphasis added). However, the Court found that the taxpayer had not experienced a more oppressive legal effect from the retroactive law at issue, and thus the Court did not reach the issue of notice. Id. at 569-71.

228. See Pension Benefit, 467 U.S. at 732; Danusmont, 449 U.S. at 299.

229. See Pension Benefit, 467 U.S. at 732 (approving the fact that various legislative proposals debated by Congress before enactment of the MPPAA uniformly included retroactive effective dates among their provisions and that such dates did not reach back before the initial introduction of the bills); Danusmont, 449 U.S. at 299 (approving the fact that the proposed retroactive increase in the tax rate had been under congressional discussion for almost a year before its enactment and thus did not pre-date the bill's introduction); United States v. Hudson, 299 U.S. 498, 501 (1937) (rationalizing that the thirty-five-day period of retroactivity imposed by a tax on silver bullion transfers was not unreasonable because the provision applied back only to its initial introduction into the legislature).

230. Untermyer v. Anderson, 276 U.S. 440, 450-51 (1928) (Brandeis, J., dissenting).

231. 276 U.S. 440 (1928).

232. Id. at 446 . 
plified in the Licari case, in which the bill provision that eventually raised the substantial understatement penalty to twenty-five percent effective retroactively was paralleled in the Congress by a similar bill which was to raise the penalty to twenty percent applicable only prospectively. ${ }^{233}$ Demanding such prescience on the part of taxpayers to guess which of these bills would pass and with what language is an impossible request. Moreover, encouraging taxpayers to gamble on which bill will succeed might produce unwanted results: Taxpayers might engage in conduct ultimately found to be detrimental or refrain from conduct ultimately found to be beneficial. Nonetheless, allowing Congress to apply a law retroactively to the time of its introduction is a practice that should not be per se unconstitutional, for situations inevitably arise in which prevention of imminent evasion is necessary. ${ }^{234}$

Beneath the debate on the materiality of the notice requirement lies the additional, and perhaps more controversial, question of what actually constitutes adequate notice, a point over which the majority and dissent in Carlton clashed. In contrast to the Carlton majority's assertion that notice is not automatically presumed when a tax rate is altered, ${ }^{235}$ every other circuit court that has addressed this issue accords with the Carlton dissent's contention that notice of a retroactive tax is denied only when a wholly new type of tax is enacted-a change in the rate of a tax is by its very nature reasonably foreseeable, whereas the imposition of a wholly new tax may not be so. ${ }^{236}$ Courts have considered this

233. Jack Teuber, New Substantial Underpayment Penalty to Be Clarified by IRS After Consultation with Chief Taxwriters, 33 TAX NOTES 430, 430 (1986). This fact may be especially significant when one considers that the Court in Pension Benefit emphasized that the retroactive application of the MPPAA had been uniformly included in the various bills debated by Congress, and thus the imposition of a retroactivity period was more apparent. Pension Berrefit, 467 U.S. at 732.

234. See, e.g., Pension Benefit, 467 U.S. at 730-31 (noting that elimination of the retroactivity period would have jeopardized the utility of the new legislation). In reality, the fair notice argument appears less a defense of retroactivity than a means of construing a statute as operative from the time of its original introduction.

235. Carlton v. United States, 972 F.2d 1051, 1056 (9th Cir. 1992), petition for reh'g filed, Sept. 29, 1992.

236. See Wiggins v. Commissioner, 904 F.2d 311, 314 (5th Cir. 1990); Estate of Ekins v. Commissioner, 797 F.2d 481, 484 (7th Cir. 1986); Fein v. United States, 730 F.2d 1211, 1213 (8th Cir.), cert. denied, 469 U.S. 858 (1984); Estate of Ceppi v. Commissioner, 698 F.2d 17, 21 (1st Cir.), cert. denied, 462 U.S. 1120 (1983); Westwick v. Commissioner, 636 F.2d 291, 292 (10th Cir. 1980); Sidney v. Commissioner, 273 F.2d 928, 932 (2d Cir. 1960) (Friendly, J.). 
rule particularly applicable to income taxes-as Judge Friendly explained, "We all know that we shall get a tax bill every year, and taxpayers have learned to conduct themselves on that basis."237

This conflict between the Ninth Circuit and the other circuits has found no definitive resolution in Supreme Court caselaw. The Carlton majority noted that, although the Supreme Court decisions of Hemme and Darusmont did not involve wholly new taxes, the Supreme Court engaged in a thorough analysis of the circumstances of each retroactive application. ${ }^{238}$ Whether, as argued by the majority, this fact "clearly indicates" that the wholly new tax rule is not endorsed by the Supreme Court is debatable. Although the Court in Hemme did not end its analysis after finding that the tax involved was not wholly new, this finding did seem dispositive with respect to the issue of notice. ${ }^{239}$ Likewise, in Darusmont, the Court used the new tax rule to resolve the taxpayer's charge of lack of notice, even though the Court continued to examine the remainder of the taxpayer's defenses. ${ }^{240}$

Thus, it remains uncertain whether the majority in Carlton could properly find insufficient notice where the tax at issue was not wholly new. Nevertheless, notions of fairness suggest that the ambiguity be resolved in favor of the Carlton majority, for the other circuits have extended the wholly new tax rule beyond income tax environs and have increasingly narrowed the definition of what is a new tax to the point where it is difficult to imagine any tax that would be considered wholly new. ${ }^{241}$ For example, several lawsuits arose when Congress retroactively excluded life insurance policies from an estate tax law that had previously permitted the exclusion of any gifts under $\$ 3,000$ made shortly before death, regardless of their form. ${ }^{242}$ Despite the fact that the new

237. Sidney, 273 F.2d at 932 (quoting Untermyer v. Anderson, 276 U.S. 440,446 (1928)).

238. Carlton, 972 F.2d at 1056.

239. See United States v. Hemme, 476 U.S. 558, 568 (1986) ("Moreover, Untermyer involved the levy of the first gift tax; its authority is of limited value in assessing the constitutionality of subsequent amendments that bring about certain changes in operation of the tax laws, rather than the creation of a wholly new tax.").

240. United States v. Darusmont, 449 U.S. 292, 300 (1981) ("Appellee's 'new tax' argument is answered completely by the fact that the 1976 amendments to the minimum tax did not create, a new tax.").

241. Notably, no court since Welch has held that a retroactive law at issue was in fact a wholly new tax.

242. Estate of Ekins v. Commissioner, 797 F.2d 481 (7th Cir. 1986); Reed v. United 
law "wholly destroy[ed] the application of the $\$ 3,000$ exemption to a distinct kind of property-policies of life insurance," the Eighth Circuit held that this was "not significant enough to make a constitutional difference."243 In other words, no gift or estate tax can be considered a "wholly new tax," as gift and estate taxes already exist; thus, any new gift or estate tax is still considered merely a rate change.

This swallowing of the notice rationale by the wholly new tax rule reflects the erosion of due process protection since Welch. The Carlton majority's holding that the absence of a new tax is not dispositive of adequate notice is a more reasoned and judicious reading of the caselaw and a necessary means of protecting the public from retroactive changes that reach an excessive number of years into the past.

3. Strike Three? Voluntary Conduct/Detrimental Reliance. A third basis for examining retroactive laws is the argument emphasized in Welch that retroactive changes to laws that affect citizens' voluntary acts are more offensive to due process than those that affect merely involuntary conduct. ${ }^{244}$ Distinguishing prior cases which struck down retroactive gift and estate taxes, ${ }^{245}$ the Court in Welch emphasized the voluntariness of the affected conduct:

In the cases in which this Court has held invalid the taxation of gifts made and completely vested before the enactment of the taxing statute, decision was rested on the ground that the nature or amount of the tax could not reasonably have been anticipated by the taxpayer at the time of the particular voluntary act which the statute later made the taxable event. Since, in each of these cases, the donor might freely have chosen to give or not to give, the taxation, after the choice was made, of a gift which he might well have refrained from making had he anticipated the tax, was thought to be so arbitrary and oppressive as to be a denial of due process. ${ }^{246}$

States, 743 F.2d 481 (7th Cir. 1984); Fein v. United States, 730 F.2d 1211 (8th Cir.), cert. denied, 469 U.S. 858 (1984).

243. Fein, 730 F.2d at 1213-14.

244. Welch v. Henry, 305 U.S. 134, 147 (1938).

245. See Coolidge v. Long, 282 U.S. 582 (1931); Untermyer v. Anderson, 276 U.S. 440, 445 (1928); Blodgett v. Holden, 275 U.S. 142, 147 (1927); Nichols v. Coolidge, 274 U.S. 531,542 (1927).

246. 305 U.S. at 147 (citations omitted). 
Explaining that "a tax on the receipt of income is not comparable to a gift tax,"247 the Court characterized the receipt of income as involuntary conduct since it is unreasonable to believe that a stockholder would refuse income simply because it will be taxed. ${ }^{248}$ This notion of voluntary conduct is interchangeable with the notion of detrimental reliance set forth by the Carlton majority. If a citizen would not have altered his conduct despite knowledge of the retroactive law, then it follows that he did not rely on the law as it stood prior to the retroactive change.

The vitality of the voluntary conduct analysis employed in Welch remains unclear, as courts have only sporadically raised this rationale and have differed regarding its importance. Whereas some courts have sustained retroactive laws because citizens would not have acted differently, ${ }^{249}$ other courts have failed even to raise the voluntariness factor. ${ }^{250}$ Ironically, the Ninth Circuit in a prior decision, Purvis v. United States, ${ }^{251}$ implicitly rejected the appropriateness of the voluntariness inquiry that it would later adopt in Carlton. In Purvis, the taxpayer challenged the retroactive application of the Interest Equalization Tax Act of 1964, which placed a tax upon purchases by Americans of foreign securities in an attempt to restrict long-term capital outflow from the United

247. Id. at 148.

248. Id. In fact, the Court treated the taxpayer's due process claim not as an assertion of destroyed reliance, but rather as an allegation of annoyance: "The objection to the present $\operatorname{tax} .$. is addressed only to the particular inconvenience of the taxpayer in being called upon, after the customary time for levy and payment of the tax has passed, to bear a governmental burden of which it is said he had no warning and which he did not anticipate." Id.

249. See, e.g., Canisius College v. United States, 799 F.2d 18, 26 (2d Cir. 1986) ("Another factor to be considered in assessing the constitutionality of a retroactive statute is whether the taxpayer relied on prior law so that, had he been able to foresee enactment of the legislation, he would have acted to avoid the tax."); Estate of Ekins v. Commissioner, 797 F.2d 481, 485 (7th Cir. 1986) (finding that the taxpayer would still have transferred the life insurance policy regardless of the new law); Fein v. United States, 730 F.2d 1211, 1213 (8th Cir.) ("There is no reason to suppose that, had he known the law would later be changed, he would have kept the policy for himself, or never have bought it to begin with."), cert. denied, 469 U.S. 858 (1984); Wilgard Realty Co. v. Commissioner, 127 F.2d 514, 517 (2d Cir.) (finding that the petitioner had done nothing it would not have done had it known of the new law), cert. denied, 317 U.S. 655 (1942).

250. See, e.g., Robinson v. Sullivan, 905 F.2d 1199 (8th Cir. 1990); Wiggins v. Commissioner, 904 F.2d 311 (5th Cir. 1990); Estate of Ceppi v. Commissioner, 698 F.2d 17 (1st Cir.), cert. denied, 462 U.S. 1120 (1983).

251. 501 F.2d 311 (9th Cir. 1974), cert. denied, 420 U.S. 947 (1975). 
States. ${ }^{252}$ The court rejected the taxpayer's argument that Welch did not permit retroactive application of "new and novel taxes upon transactions theretofore free from taxation" and which were "imposed upon a voluntary act,"253 holding instead that there is "no such rigid standard of constitutionality in the decided cases [on retroactive taxes]."254 The dissent argued that Welch explicitly distinguished prior cases striking down retroactive gift and estate taxes on the basis that a tax on income was involuntary in nature. ${ }^{255}$ Noting that the equalization tax was primarily regulatory, the dissent argued that the taxpayer "may well have not continued to invest in the foreign market since the tax was so substantial as practically to eliminate the likelihood of profit."256 Yet despite the voluntary nature of the retroactive tax, the Ninth Circuit majority seemed to abandon the voluntariness determination as irrelevant to the law's constitutionality.

This conflict in the circuit courts has not been resolved by the Supreme Court. In Turner Elkhorn, the Court seemed to accept the idea that the voluntariness of the activity regulated affects the constitutionality of the retroactive law, for the Court rejected as rationales for retroactivity the theories of deterrence and blameworthiness, in part because the parties might have acted differently had they been aware of the new law. ${ }^{257}$ Cases after Turner Elkhorn have been similarly ambiguous in their recognition of the voluntary conduct concept. In Darusmont, the Court avoided addressing the validity of what appeared to be a voluntary conduct argument by stating that such a consideration was inapplicable to income taxes. ${ }^{258}$ Moreover, in Pension Benefit, ${ }^{259}$ Hemme, $^{260}$ and General Motors Corp. v. Romein, ${ }^{261}$ the Court made no reference to the voluntariness of the citizens' conduct. Finally, although no explicit mention of this criteria is made in United States

252. Id. at 312 .

253. Id. at 313 .

254. Id. (quoting First Nat'l Bank in Dallas v. United States, 420 F.2d 725, 730 (Ct.

Cl.), cert. denied, 398 U.S. 950 (1970)).

255. Id. at 315 (Wallace, J., dissenting).

256. Id.

257. Usery v. Turner Elkhorn Mining Co., 428 U.S. 1, 17-18 \& n.16 (1976).

258. United States v. Darusmont, 449 U.S. 292, 299 (1981) (per curiam).

259. Pension Benefit Guar. Corp. v. R.A. Gray \& Co., 467 U.S. 717 (1984).

260. United States v. Hemme, 476 U.S. 558 (1986).

261. 112 S. Ct. 1105 (1992). 
v. Sperry Corp. ${ }^{262}$ one can detect its underlying presence in the Court's holding, for the facts suggest that the claimant Sperry would still have used the Claims Tribunal to validate its twomillion-dollar settlement even had it been aware that it would be charged a user fee. Indeed, failure to use the Tribunal would have precluded Sperry from legitimately receiving its settlement. ${ }^{263} \mathrm{Al}-$ though the Court did not explicitly ground its holding on this basis, it is difficult to ignore the likely weight of this fact.

Despite the Court's indeterminate attitude toward the notion of detrimental reliance, "discerning commentators and judges have suggested that the true test of the constitutionality of a retrospective law is whether a party has changed his position in reliance upon the existing law, or whether the retrospective act gives effect to or defeats the reasonable expectations of the parties."264 The voluntariness of a taxpayer's conduct offers a rational means for analyzing different retroactive taxes, for if certain acts are not governed by choice, then ostensibly no reliance is upset by the retroactivity. However, characterizing the receipt of income as an involuntary act ignores the reality of income sheltering and planned tax strategy. ${ }^{265}$ Investments are often made in different properties so as to take advantage of tax deductions, credits, and exclusions. To change the nature of these properties by imposing a new or higher tax upon income derived from them disturbs a past expectation, particularly since such investments were voluntary acts guided by current law. The Court seems to mistake the activity being upset; whereas the actual receipt may be "involuntary," the original investment in the income-generating source certainly is not. An investor who chooses to invest in corporate bonds rather than taxexempt municipal bonds looks to the after-tax yield. A retroactive increase in rates on taxable income unjustifiably changes the strike zone after the investor has swung at the ball. Finding choice on the part of a donor but constraint on the part of a receiver of income when both have equally relied upon past law to govern their actions (the donor in making his gift and the receiver in

262. 493 U.S. 52 (1989).

263. Id. at $56-57$.

264. Hochman, supra note 5, at 696 (footnote omitted).

265. See id. at 707 n.76 ("Arguably, a taxpayer may have shifted mcome to another tax year or perhaps even have changed the character of the income, but apparently the Court has not considered these tax-minimizing arguments substantial enough to affect the constitutionality of the [retroactive] statutes."). 
investing in the income-generating source) seems a weak attempt at dismissing the inequity of a retroactive income tax.

In addition to the inherent infirmities of the voluntary/involuntary comparison, a further difficulty arises as to the meaning of "detriment." The Court in Hemme asserted that the amount of the burden imposed on the citizen by the retroactive law is relevant to the law's constitutionality. ${ }^{266}$ Moreover, at least one lower court has explicitly used this factor to deny a taxpayer's challenge. ${ }^{267}$ In one sense, while it is proper to demand that a citizen must suffer before challenging a retroactive law, allowing a court to determine whether the degree of the loss satisfies the "detriment" factor inappropriately substitutes the court's notions of injury for those of the individual citizen. However, the existence of only a de minimis burden on the citizen may suggest that the citizen might not have acted differently even if the new law existed when the conduct at issue occurred. This point thus suggests the relevance of such an impact inquiry to the determination of the constitutionality of a retroactive law as applied to the complaining party.

\section{The Final Score: Drawing Conclusions from the Caselaw}

The problems arising from the Ninth Circuit's review of the retroactive penalty involved in Licari and the tax deduction retroactively eradicated in Carlton stem in part from the prior decisional law relied upon by the court. The foregoing examination of the precedent that has shaped this area of law results in four main conclusions. First, the Supreme Court's independent development in two differing series of cases of the "extremely weighty deference" accorded tax laws and the "strong deference" accorded other economic legislation has resulted in two purportedly distinct standards of review that have not been (if they can be) adequately distinguished. Licari is the first opinion to analyze these two doctrines side by side; and the Ninth Circuit's struggle over which

266. United States v. Hemme, 476 U.S. 558, 571 (1986) ("While the amount of tax is not dispositive, it is one circumstance of the transaction to be considered under Milliken [v. United States, 283 U.S. 15 (1931)].").

267. Appendrodt v. United States, 490 F. Supp. 490, 493 (W.D. Pa. 1980) ("[T]he retroactive application of Section 56 adds only $\$ 1,253.12$ to plaintiffs existing tax liability for 1976. Such limited retroactivity, producing a small incremental tax burden, does not produce a result which is so 'harsh and oppressive' as to implicate the due process clause."). 
standard of review to apply, and how to apply it, illustrates the confusion and uncertainty currently surrounding these doctrines.

Second, due to the significant benefits and burdens to individual taxpayers adjustable through tax legislation, retroactive tax laws should be accorded the same standard of review as economic legislation generally. Rather than attempt to articulate a workable distinction between the tax deference and general deference doctrines, the Supreme Court should instead abolish the distinction altogether and review retroactive tax laws and other retroactive economic laws with the same degree of scrutiny. The considerable similarity in the rationales offered to justify tax retroactivity and other economic retroactivity encourages the adoption of such a uniform standard, especially when current practice has only fostered the superficial separation of tax laws from other economic laws. Under a single approach, differences between types of tax laws would remain relevant considerations as to the validity of the retroactivity, but the lumping of all taxes into an "extreme deference" category would be abolished. ${ }^{268}$ Thus, the ESOP tax deduction in Carlton would not be grouped with revenue-raising income taxes (such as the minimum tax in Darusmont), since the ESOP deduction was enacted specifically to encourage conduct by a taxpayer. Furthermore, a uniform standard would eliminate the current confusion over which elements are relevant to an inquiry into retroactive tax laws versus retroactive economic laws generally and therefore produce greater uniformity in the field.

Third, the two doctrines have enabled courts to pay only lip service to the due process concerns involved with retroactive economic laws. Courts' succumbing to the temptation to justify retroactive laws with the same arguments used to justify prospective measures renders meaningless the already lenient level of review demanded by the Supreme Court. At a bare minimum, courts must recognize this pitfall and avoid its repetition.

Finally, applying the "mere rationality" level of review delineated by the Supreme Court to retroactive economic laws is incon-

268. Cf. First National Bank in Dallas v. United States, 420 F.2d 725, 729 (Ct. Cl.) ("Quite obviously, the considerations underlying different types of tax statutes are not uniform. Indeed, tax statutes commonly vary with respect to, inter alia, their underlying congressional intent, the transactions or interests upon which they are levied, their economic purpose, and perhaps even their social function."), cert. denied, 398 U.S. 950 (1970). 
sistent with due process, the teachings of jurisprudence, and common sense. Just as the law is not supposed to be secreted away so as to prevent the learning of its strictures, so too the law ought not operate retroactively, and thereby deny notice and disrupt settled transactions, without greater reasons for such legislation. Part IV proposes a due process analysis with a standard of review that appropriately balances the competing interests involved while attempting to assimilate the multiple rationales that have to date been inconsistently forwarded by courts.

\section{A FIELD OF DREAMS: REINVIGORATING JUDICIAL SCRUTINY OF RETROACTIVE ECONOMIC LEGISLATION}

Applying the same leniency used to analyze prospective economic legislation to retroactive legislation unjustly ignores the greater offensiveness of retroactive laws and creates too great a division between the complete prohibition of retroactive criminal penalties under the Ex Post Facto Clause and the essentially complete allowance of retroactive civil penalties under the Due Process Clause. Requiring courts to consider merely whether the retroactive aspect of a law has a rational purpose substantially discounts the uncomfortable truth that retroactive laws, unlike prospective ones, often impose unexpected burdens that cannot be avoided. Although it is understandable that courts shun the role of a "superlegislature" that conducts its own weighing of the appropriateness of a law adjusting economic benefits and burdens, such abdication becomes inapposite when an additional constitutional element, such as retroactivity-an element that the Court has already admitted invokes some sort of due process protection-is present. ${ }^{269}$

269. Consider the commercial speech doctrine that prevails under First Amendment caselaw. See Central Hudson Gas \& Elec. Corp. v. Public Serv. Comm'n of New York, 447 U.S. 557 (1980). Although Justice Rehnquist has argued that laws regulating commercial speech merely adjust the burdens and benefits of the economy and thus deserve no more protection than that provided under substantive due process, id. at 591 (Rehnquist, J., dissenting) (" $[\mathrm{B}] \mathrm{y}$ labeling economic regulation of business conduct as a restraint on 'free speech,' [the Court has] gone far to resurrect the discredited doctrine of cases such as Lochner .... New York's order here [banning all ads that promote the use of electricity] is in my view more akin to an economic regulation to which virtually complete deference should be accorded by this Court.") (citations omitted), the Court has rejected this approach because of its recognition that economic laws, coupled with the element of speech protected under the First Amendment, mandate a heightened scrutiny. Id. at $561-63,571$. Similarly, the addition to economic laws of retroactivity (protected under due 
The tracing in Part III of the various theories used to justify the retroactive application of economic laws suggests that courts have not always applied a strict minimum rationality analysis, but rather have engaged in a silent, if not explicit, balancing of the interests of the legislature and the affected party. Notions of voluntary conduct, notice, and short periods of retroactivity relate less to the rationality of a legislature's purposes than to the strength or weakness of a citizen's position under due process. The majority in Carlton properly sought to vitalize the Due Process Clause by specifying issues of notice and reliance as relevant, concrete elements of due process review. Such an interpretation of due process promotes a higher and more appropriate level of scrutiny than the "wholly new tax" rule asserted by the dissent and seemingly favored by the vast number of lower federal court decisions. ${ }^{270}$ The Carlton court's attempt to decipher and refine the due process protection accorded retroactive laws in the economic arena prompts consideration of the possible alternative standards to strict rational relation that could logically and appropriately govern a court's due process review. Possible approaches to a due process analysis include: first, the Carlton two-pronged test; second, an intermediate level of review that corresponds to the scrutiny accorded gender-based laws; and third, a four-part balancing test that resembles the analysis employed by courts when examining legislation that is alleged to violate the Contract Clause.

\section{A. The Carlton Two-Pronged Approach}

The two-pronged test proposed by the Carlton majority, which examines whether the taxpayer had received notice of the retroactive change in the law and whether he detrimentally relied upon the law prior to its retroactive change, affords genuine protection for taxpayers, particularly in light of the majority's continued refusal to find notice as long as the tax is not "wholly new."271 As noted in Part III, courts have construed the wholly new tax rule so expansively that its application has effectively destroyed the usefulness of notice as a criterion for invalidating retroactivity. ${ }^{272} \mathrm{By}$

process) ought to warrant a higher degree of scrutiny.

270. See supra text accompanying notes $235-43$.

271. Carlton v. United States, 972 F.2d 1051, 1056 (9th Cir. 1992), petition for reh'g filed, Sept. 29, 1992.

272. See supra text accompanying notes $235-43$. 
finding that the taxpayer in Carlton did not have notice of the retroactive removal of the estate tax deduction despite the fact that Congress was merely "altering" an existing tax rate, the majority has revived the notice inquiry, an important step given the historical intertwining of due process and the concept of notice. ${ }^{273}$

However, the Carlton analysis has a major shortcoming: It does not examine the equities of a case or the necessity of the retroactivity period, an undesirable restriction on both the government and the individual citizen. For legislatures, requiring notice without any countervailing equity analysis would prevent the enactment of any law with a retroactivity period predating its first introduction into the legislative process. ${ }^{274}$ Thus, under Carlton, the penalty imposed in Licari would be ipso facto invalid because the four-year period predated the initial discussion of the penalty in Congress. The Carlton majority escaped this problem by distinguishing Licari as a case involving taxpayers who were guilty parties. Thus, contrary to the explicit wording of their test, the majority appears to recognize some type of implicit equitable analysis. It is just such an inquiry that ought to become a visible part of the due process test, rather than a subtle consideration. As for the importance of an equitable analysis to individual citizens, such an inquiry can form a basis for challenging the penalty in Licari by revealing the improper (revenue-raising) motivation for and unnecessary duration of the retroactivity period. Thus, the Ninth Circuit's two-part analysis provides an improved yet incomplete reconciliation of prior cases.

\section{B. An Intermediate Level of Scrutiny}

An alternative to the Carlton court's approach is the adoption of an intermediate level of scrutiny under which a law will be invalidated if the plaintiff can demonstrate that the retroactivity is not substantially related to an important government interest. Such a mid-level inquiry, which the Court has adopted in the equal protection area with respect to gender-based laws, ${ }^{275}$ would recognize retroactive laws as a specially suspect category requiring

273. See supra Section I(A).

274. However, courts could maintain that, with respect to income taxes, such notice is considered constructively received merely by the very nature of such a tax.

275. Cf. Craig v. Boren, 429 U.S. 190, 197 (1976). 
important policy considerations for their enforcement. Some cases have in fact reaffirmed the constitutionality of retroactive economic legislation through language that would satisfy such a standard. ${ }^{276}$ Although clearly contradictory to the Supreme Court's current articulation of the proper standard of review, an intermediate level of scrutiny would greatly augment the public's protection from laws that disturb settled expectations and deny notice. However, adherence to this level of scrutiny would appear not fully compatible with the outcomes of the Court's earlier cases.

With respect to retroactive economic laws generally, the Turner Elkhorn-Pension Benefit-Sperry line of cases appears to be justified on grounds somewhat higher than mere reasonableness, even though the statutes were scrutinized under a rational basis standard. In Turner Elkhorn, ${ }^{277}$ there appears to have been a substantial interest in providing for workers who were victimized to the benefit of the mining companies. In Pension Benefit, ${ }^{278}$ the evidence showed that there was a substantial likelihood that the purpose of the law would be defeated if too much early withdrawal occurred. And in Sperry, ${ }^{279}$ it stands to reason that there was a substantial interest in ensuring that all successful Tribunal claimants bore the costs of the program equally without unnecessarily burdening those whose awards were delayed until after the legislation.

In contrast, the Court's decision in Hemme $e^{280}$ seems more difficult to justify under an intermediate level of scrutiny. The government's interest in Hemme was the desire to prevent taxpayers from gaining the double benefits that might arise from the

276. See, e.g., Usery v. Turner Elkhorn Mining Co., 428 U.S. 1, 44 (1976) (Powell, J., concurring in part and concurring in the judgment) ("Congress had broad discretion in formulating a statute to deal with the serious problem of pneumoconiosis affecting former miners.") (emphasis added); First Nat'l Bank in Dallas v. United States, 420 F.2d 725, 731 (Ct. Cl.) ("That the public purpose served by the procedures invoked at the time of, and prior to, enactment was of the higbest order cannot seriously be questioned."), cert. denied, 398 U.S. 950 (1970).

277. Usery v. Tumer Elkhorn Mining Co., 428 U.S. 1 (1976); see supra text accompanying notes $42-48$.

278. Pension Benefit Guar. Corp. v. R.A. Gray \& Co., 467 U.S. 717 (1984); see supra text accompanying notes 49-56.

279. United States v. Sperry Corp., 493 U.S. 52 (1989); see supra text accompanying notes 57-58.

280. United States v. Hemme, 476 U.S. 558 (1986); see supra text accompanying notes 101-05. 
transition to a new unified tax scheme. ${ }^{281}$ That preventing such gains to taxpayers (and losses to the Treasury) constitutes a substantial governmental interest seems unlikely. Indeed, justifying any tax law under such a standard might prove exceptionally difficult.

In the end, however, an intermediate scrutiny analysis proves one-sided and thus possesses the same infirmities as the rational relation test espoused under the general deference doctrine. An examination of the importance and substantiality of the government's reasons for the retroactivity looks only to the legislature's interests at the expense of any inquiry into a party's reliance or notice. Failure to consider these factors promotes only an imperfect examination of the constitutionality of retroactive economic legislation while overly burdening the legislature's authority to enact such laws.

\section{A Four-Part Balancing Test}

In contrast to an intermediate level of scrutiny that fails to consider the interests of both the government and the citizen, and in contrast to the Carlton two-part test that does not incorporate fully the rationales relevant to a due process review, courts should instead employ a reinvigorated rationality inquiry that concentrates on four elements: (1) the existence or absence of notice, (2) the reliance interests of the affected parties, (3) the equities of imposing the retroactive burdens, and (4) the statutory provisions that limit and moderate the impact of the burdens. Imposing such a balancing test is less an exhumation or a resuscitation of due process than a formal recognition of the balancing that has either explicitly or implicitly underlain the modern caselaw. ${ }^{282}$

More palatable than the Ninth Circuit's two-part analysis, this four-part test provides citizens with constitutional protection without depriving government of the power to enact retroactive laws when the reasons are sufficiently strong. Moreover, this proposed test strongly parallels the inquiry used by courts when examining

281. 476 U.S. at $561-62$.

282. See Demars, supra note 14, at 266-67 (stating that the Court in Turner Elkhorn "weighed the legislative and sociatal [sic] reasons for enacting the statute against the coal operators' economic reasons for not paying pre-enactment claims . . . and constitutionally balanced the policy implications for and against [it]"); Hochman, supra note 5, at 694 ("[T]lie Court has consistently held that not all retrospective statutes are unconstitutional, but only those which, upon a balancing of the considerations on both sides, are felt to be unreasonable."). 
the constitutionality of legislation challenged under the Contract Clause. ${ }^{283}$ Although not fully analogous, the scrutiny employed in the Contract Clause context provides insights and guidance as to the type of analysis that should govern a due process review. Indeed, authorities have historically construed the protection against retroactive laws offered by these different constitutional provisions as intertwined. ${ }^{284}$ However, despite the similarities of the two inquiries with respect to retroactivity, the Supreme Court in Pension Benefit refused to look to Contract Clause cases as valid sources of guidance for due process review, stating that it had never before explicitly held that the two inquiries were coextensive. ${ }^{285}$

283. For an illustration, see Nachman Corp. v. Pension Benefit Guar. Corp., 592 F.2d 947, 958-63 (7th Cir. 1979), aff'd on statutory grounds, 446 U.S. 359, 367-68 \& n.12 (1980), where the Seventh Circuit analyzed both Contract Clause and due process cases to formulate the appropriate rationality analysis to employ when examining the constitutionality of ERISA's retroactive imposition of liability on employers who had disclaimed contractually the owing of such benefits:

Rationality must be determined by a comparison of the problem to be remedied with the nature and scope of the burden imposed to remedy that problem. In evaluating the nature and scope of the burden, it is appropriate to consider the reliance interests of the parties affected, whether the impairment of the private interest is effected in an area previously subjected to regulatory control, the equities of imposing the legislative burdens, and the inclusion of statutory provisions designed to limit and moderate the impact of the burdens.

592 F.2d at 960 (citations omitted). The Supreme Court has not challenged the validity of the Nachman court's four-part test as it relates to a Contract Clause analysis. $C f$. Pension Benefit Guar. Corp. v. R.A. Gray \& Co., 467 U.S. 717, 732-33 (1984) (rejecting the application of this four-part test with respect to a due process analysis of retroactive economic laws because the test relies primarily on Contract Clause cases); Energy Resources Group, Inc. v. Kansas Power \& Light Co., 459 U.S. 400, 410-13 (1983) (recognizing the role of these four elements in an analysis under the Contract Clause).

284. Allied Structural SteeI Co. v. Spannaus, 438 U.S. 234, 262 n.9 (1978) (Brennan, J., dissenting); Home Bldg. \& Loan Ass'n v. Blaisdell, 290 U.S. 398, 448 (1934); Robert L. Hale, The Supreme Court and the Contract Clause, 57 HARv. L. REv. 852, 891 (1944) ("[T]here is at least a tendency for the contract clause and the due process clause to coalesce."); Hochman, supra note 5, at 695 ("[S] everal cases have indicated that the standard of reasonableness under the contract clause is the same as that utilized in determining the validity of retrospective legislation under the due-process clauses of the fifth and fourteenth amendments."); Slawson, supra note 198, at 221 ("No Supreme Court decision in the last 25 years dealing with contracts has been found that did not contain language to the effect that what was said about the contract clause was equally applicable to the claimant's charge that he was being deprived of property without due process of law.").

285. Pension Benefit, 467 U.S. at 733. The Court relied on United States Trust Co. v. New Jersey, 431 U.S. 1, 17 n.13 (1977), for its assertion that the Contract Clause imposes more searching standards on economic legislation than do the Due Process Clauses. However, footnote 13 does not stand for the proposition that guidance as to a due process analysis cannot be found in the caselaw developed in the Contract Clause context. Rath- 
This unsatisfactory dismissal of the rationality analysis used in Contract Clause cases has only maintained the uncertainty and insufficiency of current due process review. An examination of the four factors and their application demonstrates how criteria used to review Contract Clause claims are applicable in the due process field and achieve the fair resolution of such challenges.

1. Notice. Courts should find adequate notice only if the retroactivity period begins after the law's initial public introduction. ${ }^{286}$ Legislation that extends before this period, like the legislation in Licari and Carlton, ought to be considered more suspect, and courts should not hesitate to hold that notice of such legislation does not exist. This construction thus repudiates the overly expansive presumption that only taxes that are "wholly new" deny notice; it further rejects the argument that notice arises whenever an act that is applied retroactively is one within the power of the legislature to enact, for to hold otherwise excessively broadens the legislature's powers. ${ }^{287}$ Importantly, this bright-line interpretation

er, it merely restates the rule set forth in Welch that retroactive civil legislation does not violate due process unless the consequences are particularly "harsh and oppressive."

286. Although the meaning of "initial public introduction" eludes precise definition, the term certainly includes the introduction of a bill into Congress that states that its effective date will be from introduction (as opposed to from enactment). Thus, a bill only provides notice froin the time it is stated that it will apply retroactively. As for presidential requests for certain legislation (such as Kennedy's request to Congress to impose an interest equalization tax that was the subject of Purvis v. United States, 501 F.2d 311 (9th Cir. 1974), cert. denied, 420 U.S. 947 (1975), and First National Bank in Dallas v. United States, 420 F.2d 725 (Ct. Cl.), cert. denied, 398 U.S. 950 (1970), the intense media coverage that the press provides to the public on executive decisions and policies should lead to the conclusion that presidential public announcements (such as through a press conference or letter to Congress) provide adequate notice, regardless of the absence of any language requesting that the policy be given a retroactive effective date.

The thornier issue involves whether certain action called for in a senator's or congressman's speech, but not yet translated into a bill, constitutes adequate notice. As public knowledge of such a speech depends on the prominence of the speaker and the arena where it is spoken, the best method for resolving the issue of notice is application of a reasonable person standard, whereby the court determines whether a reasonable person would have received notice froin such a speech.

287. This point is strongly made by Charles Hochman:

[A] sweeping principle [from many of the Supreme Court's cases] is that the parties are on notice that if the legislature has competence in a given field, it may well exercise its powers, and therefore there is no unfair surprise when these powers are exercised retroactively. This statement of the rule appears to be too broad since it in effect makes retroactivity inmaterial in determining the constitutionality of a statute; if the legislature could act as it did by a statute which had prospective application only, it can make the statute apply to past transactions. Such a rule would greatly reduce the certainty with which a person 
of the notice requirement does not unduly restrain legislative action, for a finding of inadequate notice does not require the automatic invalidation of the retroactive law. Rather, it is simply one factor to be balanced against the findings under the other three criteria.

2. Reliance. The element of detrimental reliance has already been explicitly asserted by Carlton as an important consideration. ${ }^{288}$ This factor recognizes that a retroactive law may be less offensive if a party had no prior reasonable expectations. Because the reasonableness of a party's reliance turns in part on his awareness of the retroactive law, the question of detrimental reliance is closely tied to the issue of notice that forms the first prong of the analysis. Although a finding that a party had notice of the impending retroactive law defeats an assertion of reliance, a finding of inadequate notice does not necessitate the opposite holding. Thus, while the notice and reliance elements are connected, they are nonetheless divisible components that require independent inquiry.

With respect to the reliance issue, the type of law being changed retroactively is a relevant consideration, for a law designed to encourage activity (as in Carlton) generally produces greater reliance than a law that merely regulates without inducing specific conduct. Although both tax and other economic laws should be subject to a similar inquiry in determining reliance, the Court's strong historical acceptance of the constitutionality of retroactive income tax laws that reach back to the year of enactment, to the year preceding enactment, or to the "first opportunity" the legislature had to enact the law, serves to prevent a taxpayer from claiming reasonable reliance on a prior income tax law that falls within this permissible retroactivity period. ${ }^{289}$ This temporal limi-

could plan his conduct, since the legislature might change the legal effect of past transactions at will.

Hochman, supra note 5, at 700 (footnote omitted). Hochman also notes that

[t]his rule would place complete reliance for the protection of property and contractual rights on the judgment of the legislature, which is more likely to be influenced by political forces and the apparent necessities of a temporary situation than is the Court. The desirability of retaining the Court as the fmal arbiter on these matters seems clear.

Id. at 700 n.45.

288. Carlton v. United States, 972 F.2d 1051, 1065 (9th Cir. 1992), petition for reh'g filed, Sept. 29, 1992.

289. Welch v. Henry, 305 U.S. 134, 148-51 (1938). This rule would limit the construc- 
tation, combined with the "first opportunity" concept, accommodates the rationale of legislative necessity ${ }^{290}$ and simultaneously provides taxpayers with greater certainty as to the period of time during which they may be liable for additional income taxes-a desirable function that resembles that served by statutes of limitation. ${ }^{291}$ Additionally, an inquiry into reliance includes consideration of the amount of the new liability imposed on the citizen, for a small burden might serve as evidence disproving the assertion that the citizen would have acted differently had he been aware of the new legislation. ${ }^{292}$

3. Equity. The four-part rationality test also incorporates an equity analysis that allows a court to balance the reasonableness of the government's interests with the actions and interests of the citizen. Rather than being an original requirement, the equity element serves more to formalize the implicit equity analysis that already pervades much of the caselaw. ${ }^{293}$ Thus, under this equity analysis, the rationality of the government's interest is examined

tive notice rationale to the formula proposed in Welch and consequently reduce the possible time period over which an income tax may be enacted retroactively to around two years. The "first opportunity" rationale should be narrowly construed so that only if the legislature could not convene would the rationale control. See also supra text accompanying notes 208-25 (discussing the notion of short-period retroactivity and its precedential value).

290. See supra text accompanying notes 214-25.

291. Although an income tax that extends beyond this traditional "grace period" will not receive the benefit of this presumption of validity, such a law inay nonetheless be upheld if the balance of the other elements favor such retroactivity, as would be required of other tax laws that are not income-related.

292. See supra text accompanying notes $266-67$.

293. See, e.g., United States v. Hemme, 476 U.S. 558, 568 (1986) (remarking that in an earlier case "the equities were especially favorable to the taxpayer"); Pension Benefit Guar. Corp. v. R.A. Gray \& Co., 467 U.S. 717, 730-31 (1984) (noting that invalidation of the retroactivity period would have undermined the prospective goals of the law and thus defeated the important purposes of the pension legislation); Usery v. Turner Elkhorn Mining Co., 428 U.S. 1, 18 (1976) (seeming to recognize the strong equities in favor of upholding the retrospective law because it would impose liability on employers who had profited from their employees' labors and risk of illness); Wesley Theological Seminary v. United States Gypsum Co., 876 F.2d 119, 122 (D.C. Cir. 1989) (finding, in upholding the retroactive effect of a statute of repose, that "defendant's equities are not especially powerful"), cert. denied, 494 U.S. 1003 (1990); First Nat'l Bank in Dallas v. United States, 420 F.2d 725, 731 (Ct. Cl.) (finding that the public purpose served by the retroactive imposition of legislation to restrict the outflow of long-term capital from the United States was of the "highest order" and that the limited restriction imposed upon the taxpayers' investment options "can hardly counterbalance the serious national purpose underlying the subject tax"), cert. denied, 398 U.S. 950 (1970). 
and compared with the private party's conduct. This analysis provides courts with the flexibility requisite to an analysis of the inherently vague protections of the Due Process Clauses. ${ }^{294}$

4. Moderation of the Burden. Strongly related to the equity inquiry, the final component is an examination of the legislature's moderation of the retroactive burden. The government must demonstrate that the length of the retroactivity period is necessary to the accomplishment of the rational government objectives; language to this effect already exists in the modern caselaw. ${ }^{295}$ This component acts as a restraint on the possible legislative impulse to push the permissible duration of retroactivity periods to greater lengths. In addition, it enables courts to consider the extent to which the legislature moderated the retroactive legislation to limit the severity or substantiality of the changes to the prior law and the extent to which the citizen is subject to any additional liability, a consideration that overlaps with a finding of reliance. Rather than replacing the legislature's judgment with that of the court, this inquiry is merely meant to allow courts to consider the extremes of retroactive liability to ensure the proper exercise of legislative powers.

5. The Test Applied. Application of this four-part balancing test shows that its analysis maintains the integrity of prior Supreme Court cases.

a. Turner Elkhorn. ${ }^{296}$ Under the four-part balancing test, the employers in the Turner Elkhorn case cannot be consid-

294. See, e.g., Murray's Lessee v. Hoboken Land \& Improvement Co., 59 U.S. (18 How.) 272, 276 (1856) ("The constitution contains no description of those processes which [due process] was intended to allow or forbid. It does not even declare what principles are to be applied to ascertain whether it be due process.").

295. See, e.g., Pension Benefit, 467 U.S. at 731 ("Congress advanced the effective [retroactive] date chosen so that it would encompass only that retroactive time period that Congress believed would be necessary to accomplish its purposes."); Canisius College v. United States, 799 F.2d 18, 26 (2d Cir. 1986) ("The length of the [retroactive] period affected is an additional factor to be considered in determining whether retroactive legislation is unduly harsh and oppressive in application."); First National Bank, 420 F.2d at 731 ("The retroactive aspect of the [interest equalizationl tax ... was no mere embellishunent; indeed, that aspect was a necessary prerequisite to the effectuation of the regulatory purpose.").

296. See supra text accompanying notes $42-48$. 
ered to have received adequate notice of the retrospective liability in the sense recognized under this analysis, for the retroactivity extended back long before the first public discussion of the new legislation. ${ }^{297}$ The second factor, that of the coal mine operators' reliance, is uncertain, for the einployers did not specifically argue that they would have taken steps to reduce or eliminate the incidence of black lung disease had the law imposed that liability on them. ${ }^{298}$ As to the third element, the equities are strongly on the side of the government, for the legislature was trying to provide for employees whose disabilities arose from past employment and to make employers who profited from dangerous work conditions partly accountable for their employees' medical expenses. Furthermore, the law moderated the impact of the burden on employers by excluding from liability coal mine operators who had only recently entered the field and thus had not grossed "excess profits" from the unsafe conditions under which the employees worked. ${ }^{299}$ Thus, a balancing of the absence of notice with the questionable existence of reliance, the strong equities favoring the retroactivity, and Congress's attempt to inoderate the burdens supports sustaining the retrospective liability.

b. Darusmont. ${ }^{300}$ With respect to the element of notice, the minimum tax in Darusmont only reached back to the beginning of the year (a period of about nine months), and thus was in accordance with long-standing legislative practice and judicial acquiescence regarding notice of retroactive income taxes. ${ }^{301}$ Moreover, as the Court noted, the change in the minimum tax had been under public discussion for over a year, ${ }^{302}$ and therefore the retroactivity period began after its initial public introduction, a fact strongly tied to the reasonableness of the taxpayer's reliance, for warning of the impending passage of the new minimum tax helps defeat the legitimacy of the alleged past expectations. Thus, even

297. The Court did note, however, that the existence of black lung disease had been known by the coal mine operators for at least 20 years before the enactment of the retrospective legislation, and thus Congress's recognition of the need to care for these injured workers could not have come as a surprise. Usery v. Turner Elkhorn Mining Co., 428 U.S. $1,17 \&$ n.17 (1976).

298. Id. at 17.

299. See id. at 18-19.

300. See supra text accompanying notes 94-100.

301. See supra text accompanying note 289.

302. United States v. Darusmont, 449 U.S. 292, 299 (1981) (per curiam). 
though the taxpayer asserted that he would have structured the sale differently had he known of the retroactive change in the minimum $\operatorname{tax}^{303}$ such reliance is better characterized as a gamble by the taxpayer that the new minimum tax of which he had constructive notice would not be retroactively applied.

With respect to the equities of the case, the minimum tax is not a tax to induce action, but rather is simply a way of calculating income to ensure that everyone pays his fair share of tax. In addition, the very nature of the minimum tax makes it administratively impossible to single out the sale of an apartment as deserving separate tax treatment since the minimum tax is a tax that depends upon all items of income and deduction. Finally, evidence of the moderation of the legislation includes Congress's application of the law back only to the year of enactment and the fact that the law did not completely remove the $\$ 30,000$ exemption but instead only lowered it to $\$ 10,000$. Furthermore, the additional liability imposed on the taxpayer was only around $\$ 2,000$. Since the gain from the sale of the apartment exceeded $\$ 50,000$, this modest liability on the taxpayer suggests that the impact of the retroactive tax was limited in its severity. Thus, a balancing of these criteria yields a strong basis for upholding the law.

c. Pension Benefit. ${ }^{304}$ In Pension Benefit, the MPPAA-requiring an employer withdrawing from a multi-employer pension plan to pay a fixed and certain debt to the plan amounting to the employer's proportionate share of the plan's unfunded vested benefits-had a retroactivity period of approximately five months. With respect to the issue of notice, the retroactivity period of the MPPAA reached back only to a time during which the law was being debated by Congress. Moreover, the different legislative proposals discussed by Congress before enactment of the MPPAA uniformly included retroactive effective dates among their provisions, further testifying to the inevitable retroactivity of the law. ${ }^{305}$ As to reliance, this case involved not only the reliance interests of the employers, but the reliance of the employees entitled to pension benefits. It is clear that employers have a substantial interest in certainty with respect to pension

303. Id. at 295.

304. See supra text accompanying notes 49-56.

305. Pension Benefit Guar. Corp. v. R.A. Gray \& Co., 467 U.S. 717, 732 (1984). 
liabilities. However, in light of the MPPAA's purpose, it is questionable whether employers who withdrew during the five-month period preceding enactment of the statute detrimentally relied on the law as it stood prior to the amendment, for it is unlikely that those employers who withdrew would not have done so even knowing the more burdensome liability imposed on them by the MPPAA. Rather, such employers were simply trying to avoid the added costs that they knew (either constructively or actually) Congress was considering imposing. In contrast, "the employees had a strong and justifiable expectation that they would receive the vested pension benefits to which they had become entitled for their years of service." 306 A balancing of these issues of reliance shows the rationality of Congress in favoring the reliance interests of the employees over the improper reliance of the employers.

The equities of the case also seem to favor retroactive liability, particularly because there is "no disabling inequity in imposing withdrawal liability on employers when the pension plans they have joined voluntarily turn out to be underfunded." 307 In addition, a failure to apply the law retroactively would reasonably have threatened the integrity of the prospectivity aspect of the MPPAA, for employers would have received an incentive to withdraw before enactment and thus undermine the health of many pension funds. Lastly, with respect to the final factor, Congress revised the retroactive date of the MPPAA several times so as to limit its duration only to that period of time it believed was necessary to prevent its evasion by wary employers-an evasion that could jeopardize the effectiveness of the MPPAA. In addition, the MPPAA has several provisions that moderate its impact, including "a variety of features that limit the standard of when a 'withdrawal' occurs, mitigate the amount of liability imposed and reduce or eliminate liability if an employer either resumes operations ... or increases its contribution base units after a complete withdrawal." ${ }^{308}$ Thus, in balancing these elements, the Court could find the MPPAA's retroactivity constitutional.

306. Peick v. Pension Benefit Guar. Corp., 724 F.2d 1247, 1271 (7th Cir. 1983), cert. denied, 467 U.S. 1259 (1984).

307. Id. at 1273. For a fuller discussion of the balancing of the equities involved in the retroactive application of the MPPAA, see $i d$. at 1273-74.

308. Id. at 1273-74 (citation and footnotes omitted). 
d. Hemme. ${ }^{309}$ The taxpayer in Hemme had constructive, if not actual, notice of the retroactive effect of the new transitional rule to the unified credit scheme enacted in the Tax Reform Act of $1976 .{ }^{310}$ Although enacted in October 1976, the transitional rule applies to all gifts made after September 8, 1976, the date when the House Conference Committee approved the measure. ${ }^{311}$ Because the actions by the taxpayer that formed the basis of the suit occurred on September 28,1976, the taxpayer was on notice of the impending transitional rule. This evidence of adequate notice also upsets the taxpayer's assertion of reasonable reliance on the prior law, for his actions are presumed to have been grounded on a desire to evade the new law's effects. ${ }^{312}$ Moreover, even if the taxpayer's actions had occurred prior to this period, the Court found that the taxpayer had not suffered any detriment due to the new law and thus was not injured.

The equities of the case also favor the government. The purpose of the transitional rule is to prevent taxpayers from receiving double tax benefits by taking full advantage of the old scheme while subsequently reaping the benefits of the new unified tax scheme. The retroactive application of the transitional rule eliminates the ability of wary taxpayers to seek deliberately the windfall of double exemption. ${ }^{313}$ This factor relates to the final prong of the test, for Congress modified the burdens of the retroactivity period by restricting it only to gifts made after the date of the approval of the measure by the Conference Committee. As the Court noted, the Committee "evidently was less concerned with the possibility of double tax benefits in general than it was with preventing the intentional accretion of such benefits."314 Thus, the existence of notice, the absence of detrimental reliance, the equities favoring the government's interests in imposing the law, and the moderation of the burdens all strongly sustain the constitutionality of the retroactive law.

309. See supra text accompanying notes 101-05.

310. The Tax Reform Act of 1976, Pub. L. No. 94-455, 90 Stat. 1520, was passed on October 4, 1976, and took effect on January 1, 1977.

311. United States v. Hemme, 476 U.S. 558, 562 (1986).

312. As the Court remarked, "[the taxpayer] evidently hoped to reap the beriefits of [the old] law before its repeal." Id. at 563.

313. Id. at 561-62.

314. Id. at 562 . 
e. Sperry. ${ }^{315}$ Although the question of whether Sperry had notice of the retroactive imposition of a fee on the users of the Iran-United States Claims Tribunal is not easily answerable, a fair reading of the facts suggests that Sperry did. ${ }^{316}$ Although a finding of notice removes any reasonable reliance that Sperry may have alleged, it appears that Sperry likely would have used the Claims Tribunal even if it had known of the requirement of a user fee, for it had no other method for legally validating its settlement with Iran. ${ }^{317}$ As to the equities, the government's purpose in applying the user fee retroactively is to ensure "that all successful claimants before the Tribunal are treated alike in that all have to contribute toward the costs of the Tribunal." ${ }^{318}$ Applying the user fee only prospectively would result in making the costs of the Claims Tribunal fall disproportionately on the claimants whose awards were delayed, and might necessitate the imposition of an even higher user fee on these later claimants. ${ }^{319}$ Lastly, Congress moderated the legislation by making it retroactive only to the date of the issuance of the Treasury directive that the new law sought to cure. ${ }^{320}$ In addition, the retroactive user fee only applies to successful claimants, further limiting the potential harm to users of the Tribunal. Thus, a balancing of these four factors inevitably leads to the upholding of the retroactive law.

315. See supra text accompanying notes 57-58.

316. United States v. Sperry Corp., 493 U.S. 52, 56-58 (1989). Although Sperry and Iran in February 1982 reached an agreement requiring the payment by Iran to Sperry of $\$ 2.8$ million, the Government of Iran did not give the settlement fmal approval until July 1982: In the meantime, the Department of the Treasury in June 1982 issued a directive requiring the Federal Reserve to deduct two percent from each award certified by the Tribunal. Sperry challenged the validity of this directive, and the United States Claims Court in an oral ruling in May 1985 held that the directive violated the Independent Offices Appropriation Act. Shortly thereafter, Congress enacted the one-and-a-half percent user fee at issue, which it applied retroactively to June 1982, the date of the issuance of the Treasury directive. Thus, before Sperry completed its settlement with Iran, Sperry was aware of the government's attempts to impose a Tribunal user fee. Furthermore, at the time of the completion' of settlement, Sperry had no indication that the Claims Court would rule in its favor on the initial directive. Such knowledge constitutes adequate notice, even though the initial directive proved defective.

317. Id. at 56-57.

318. Id. at 64 .

319. Id. at 64-65.

320. See supra note 316. 
f. Licari and Carlton revisited. ${ }^{321}$ The successful application of the four-part balancing test to the modern Supreme Court precedents demonstrates that the test can accommodate the rulings of prior cases while serving the important function of detailing the factors to consider under a due process review. Importantly, this balancing analysis permits the invalidation of the retroactive laws in Licari and Carlton and thus reinvigorates the protections guaranteed under due process.

Application of the four-part analysis to Licari demonstrates the unconstitutionality of the retroactive application of the increased tax penalty. First, the Licaris had received no notice of the retroactive change to the penalty, for the law's retroactivity period extended back long before its initial public introduction. Second, as to the issue of reliance, the central question is whether it was reasonable for the Licaris to take a questionable tax position ${ }^{322}$ based upon a risk-reward analysis, where the risk involved a tenpercent penalty. If this is permissible reliance, then the retroactive imposition of the additional fifteen percent of the new twenty-fivepercent penalty violated the Licaris' right to rely on the law as it had existed prior to the time they took their tax position.

Third, the equities of the case, on balance, favor taxpayers. Although the Licaris themselves were rather unsympathetic parties because they knowingly understated their taxes, this fact proves irrelevant to the penalty at issue, for the penalty for substantial understatement applies equally to someone who acts in good faith. Moreover, the government's reasons for raising the penalty retrospectively are inadequate. As noted in Part II, justifying a retroactive law on the ground that it will enhance revenue and protect the public fisc promotes an interpretation of rationality that has no limits, for virtually any economic law could be justified under this rationale. ${ }^{323}$

321. See supra Part II.

322. That is, a position not supported by substantial authority. See I.R.C. \& 6662(d)(2)(B)(i) (Supp. III 1991); id. \& 6661(b)(2)(B)(i) (1982) (repealed 1989).

323. Because income taxes are often aimed solely at generating revenue, and because the Court has demonstrated a strong historic acceptance of the legitimacy of retroactive income taxes, any rejection of a revenue-raising rationale must come with a special exception for income tax laws. Failure to provide an exception for this long-standing historical practice would effectively prohibit legislatures from enacting income tax laws retroactively. However, because of the "parade of horribles" potential of the revenue-enhancing rationale, it should not gain legitimacy outside of the income tax arena. 
Finally, Congress's inadequate attempt at moderating the impact of the retroactive penalty reveals the questionable propriety of the law. The approximately four-year period of retroactivity involved in Licari reflects Congress's recognition that the longer the duration of the retroactivity period, the more revenue it can generate. However, to accept this argument as legitimate would impermissibly broaden a legislature's power to enact retroactive laws. ${ }^{324}$ Significantly, the retroactivity is not necessary to effectuate the prospective aspects of the new penalty, as might have been the case had the law been retroactively applied only to the time of its original public discussion. Nor is the retroactivity necessary to prevent taxpayers' evasion of the new penalty or to overturn an unexpected judicial interpretation of the former ten-percent penalty. Furthermore, although the retroactive law provides that those who come forward and admit their understatements after enactment of the new penalty will be subject only to the old ten-percent penalty, this exemption presumes that other taxpayers are aware of their understatements, even though the law imposes liability on non-negligent understatements made without intent or knowledge of error. In addition, despite its ostensible concession to taxpayers, this exemption in fact allows the IRS to use the heightened penalty as an unfair bargaining chip to dissuade taxpayers from asserting the legitimacy of their past income statements, for taxpayers now face a higher penalty if subsequently audited for acts completed long before the penalty's increase.

Consideration of these four factors presents the following picture: the absence of adequate notice, the questionable reliance of the Licaris, the irrational revenue-raising and fisc-guarding bases for the retroactive application versus the blameworthiness of the Licaris, and the minimal moderation of the retroactivity. Although a balancing of these factors does not mandate a finding of unconstitutionality, the inadequacy of the government's reasons for the retroactivity, the significant length of the retroactivity period, and the absence of notice ought to outweigh the marginal value of the

324. In Wilgard Realty Co. v. Commissioner, 127 F.2d 514, 517 (2d Cir. 1942), the Second Circuit remarked that "whether the period of retroactivity is comparatively long or short is of little consequence provided it isn't too long to be within reason." Under this phrasing, no retroactivity period would be too long under a revenue-raising rationale, for it is inherently reasonable to produce more income for the Treasury by extending the duration of the retroactivity period. 
blameworthiness of the taxpayers and thus invalidate the retroactive application of the heightened penalty.

Similarly, application of the four factors to the Carlton facts readily shows the unfairness of the retroactive imposition of the decedent ownership requirement. As to the issues of notice and reliance, the Carlton majority already noted the absence of any notice and the presence of detrimental reliance. Regarding the equities of the case, the government's only claim was that it had made a mistake in drafting the law and thus had permitted an unexpected loss of revenue through exploitation of this loophole. The rebuttal to this argument is the assertion that Congress knew how to write the law, and even the legislative history of the original estate tax deduction fails to show the impropriety of Carlton's discounted sale of stock to the ESOP. Finally, Congress did not limit the retroactive application of the law to its initial public introduction in January 1987, but rather applied it back to the original deduction's enactment in September 1986. Moreover, the more than $\$ 600,000$ loss imposed on the decedent's estate by the retroactive law reflects Congress's poor moderation of the burdens imposed by the retroactivity. Thus, the absence of adequate notice, the presence of detrimental reliance, the weak equities for the government, and the absence of any moderating provisions illustrate the clear unconstitutionality of the retroactive removal of the estate tax deduction as applied to Carlton.

\section{CONCLUSION}

To the degree that the law should serve as a guide for personal conduct, retroactivity upsets this purpose. Without a level of scrutiny that enables courts adequately to review such legislation, retroactive economic laws become as readily sustainable as legislation affecting only future actions. An appropriate level of review balances the need for predictability with the desire for progress in a society in flux. ${ }^{325}$ The four-part rationality test proposed in this Note offers heightened constitutional protection without sacrificing the legislature's power to enact retroactive laws. Assimilating the

325. Leedom v. International Bhd. of Elec. Workers Local 108, 278 F.2d 237, 240 (D.C. Cir. 1960); see also Slawson, supra note 198, at 226 ("[R]eliance can never be absolute, since the legal order must constantly change to fit new factual conditions or new conceptions of the common good. Reliance on existing rules, therefore, must be sacrificed to some extent to the need for change."). 
variety of rationales upon which courts have haphazardly relied and incorporating them into a more systematic framework, the four-part test provides courts with a more practical method for analyzing due process challenges to retroactive economic laws without disturbing Supreme Court precedent or unduly restricting the flexibility courts often require when interpreting the amorphous language of the Due Process Clauses. Ultimately, the reinvigorated rationality analysis not only clarifies the vague coinmands of the "harsh and oppressive" and "arbitrary and irrational" language that have long promoted inconsistent applications by courts and ignorance by litigants, but also provides the more rigorous protection from retroactive laws that due process demands. 